\title{
NUTRIENT MINERALIZATION PATTERNS IN SHELF WATERS OF THE WESTERN IBERIAN UPWELLING
}

\author{
X.A. Álvarez-Salgado*, C.G. Castro, F.F. Pérez and F. Fraga
}

Consejo Superior de Investigaciones Científicas (CSIC)

Instituto de Investigacións Mariñas

Eduardo Cabello 6, 36208-Vigo. Spain

*email: xsalgado@iim.csic.es 


\section{ABSTRACT}

A set of hydrographic data collected during several cruises to the NW Iberian upwelling system has been used to assess the patterns of nutrient mineralization over the shelf. Mineralized nutrient ratios (N/P and N/Si) in the lower water column are clearly below the ratios characteristic of freshly upwelled oceanic waters. Nitrogen mineralization, in comparison to phosphorus mineralization, is incomplete, in agreement with phosphate's faster regeneration rate and the low residence time of water, which precludes complete mineralization. Silicate shows the highest enrichment as a consequence of the selective concentration of particulate biogenic silica in the near bottom waters. Diffusion of nutrients mineralized in the sediments seems to represent an important contribution. The lowest mineralization of the surveyed area is found to the north of Cape Finisterre, especially with regard to silicate. To the South, the Rías Baixas (four large embayments) return as reducing particulate organic matter (POM) a small fraction of the upwelled nutrients imported from the shelf. However, the outflowing freshwater contributes to stratification of coastal waters, which favours POM production, accumulation and sedimentation. In addition, high levels of new dissolved organic matter (DOM) in the outflow can also enhance primary production in shelf surface waters. Finally, highest mineralization was found to the South of the River Miño, where there are no embayments and the shelf is wider. Mineralization tends to: 1) increase the potential primary production of this ecosystem by up to $50 \%$, (nitrogen limitation) or up to $80 \%$ (silicon limitation); 2) favour the development of phytoplankton assemblages dominated by diatoms ( $\mathrm{Si}$ enrichment double that of $\mathrm{N}$ and $\mathrm{P}$ ); and 3) buffer the large spatial and temporal differences introduced by the advected nutrients. 


\section{INTRODUCTION}

High primary production in coastal upwelling areas has been related to the uplift of nutrient-rich subsurface waters to the photic layer, forced by the wind-driven circulation pattern (BARBER and SMITH, 1981; WALSH, 1991). A significant part of the upwelled nutrients can be recycled over the shelf by rapid photosynthesis and subsequent mineralization of the sinking particulate organic matter (POM). The process can take place in the near-bottom onshore-flowing water and/or at the sediment-water interface, with posterior release to the overlaying water as these waters are upwelled (Rowe et al., 1975).

We shall refer to this mechanism of nutrient-trapping (REDFIELD et al., 1963) as secondary recycling, in contrast with the primary recycling that occurs in the photic layer. The major difference between these processes is the time scale involved: primary recycling (through ammonium nitrogen) takes place within the scale of phytoplankton cells doubling time, i.e. from hours to days. Secondary recycling (through both ammonium and nitrate) is time-limited between days and weeks by the physical processes involved in the mechanism of nutrient-trapping, i.e. POM horizontal transport, gravity sinking and convective-diffusive uplift of mineralized nutrients. Primary plus secondary recycling supports the regenerated production in contrast to the new production occurring via nitrate supplied from deep waters (DUGDALE and GOERING, 1967; EPPLEY and PETERSON, 1979). Secondary recycling exclusively occurs in ocean margins.

Secondary recycling is directly linked to shelf-ocean exchange processes, a subject of renewed interest during the 90's (WROBLEWSKI and HOFFMANN, 1989; MANTOURA et al., 1991). The SEEP-I (FALKOWSKI et al., 1988) and SEEP-Il (BISCAYE et al., 1994) experiments in the Middle Atlantic Bight have demonstrated that $<5 \%$ of the biogenic organic matter produced over the shelf is exported to the adjacent slope. In contrast, some authors have suggested that export to the deep slope sediments is the final fate of POM (WALSH et al.,1981; WALSH, 1989). 
Nutrient accumulation by secondary recycling has been widely described in the major upwelling areas (FRIEDERICH and CODISPOTI, 1981; MINAS et al., 1982a; CODISPOTI, 1983; BAILEY and CHAPMAN, 1985). For an upwelling system, water circulation favours POM wash-out through the shelf-edge (WROBLEWSKI and HOFFMANN, 1989), especially at points where large filaments develop (MOISAN, 1994). Downwelling fronts prevent such an exchange, enhancing POM sedimentation, and subsequently oxidation over the shelf (MONTEIRO et al., 1983). The relative importance of secondary recycling gives a clear indication on the final fate (export or oxidation) of POM. For the Iberian upwelling, nutrient accumulation by secondary recycling was first pointed out by FRAGA (1981) and recently revisited by ÁlVAREZ-SALGADO et al. (1993), who briefly studied the time variation of the phenomenon.

The aim of the present work is to establish the spatial distribution of nutrient enrichment by secondary recycling in the near bottom water column of the NW Iberian upwelling. A simple mixing model will be applied to a hydrographic data set, collected from several cruises, which covers different seasonal and dynamic conditions. In this sense, we try to contribute to further 'process orientated' studies on the region in the manner pointed out by FRIEDERICH and CODISPOTI (1979): "analysis of routinely collected data shows how these abundant results (hydrographic data) can aid in choosing the collection sites for powerful but difficult techniques".

\section{MATERIAL AND METHODS}

\section{Survey area}

This study covers the northwestern corner of the Iberian Peninsula, from Cape Peñas in the Cantabrian Sea to Cape Mondego on the Portuguese coast (Fig. 1). Data were collected during five cruises carried out by the Oceanography Group of the Instituto de Investigacións Mariñas de Vigo, between 1984 and 1993.

The shelf of the western Iberian Peninsula is affected by the intermittent upwelling of the cold and nutrient-rich Eastern North Atlantic Central Water, ENACW 
(FrAGA, 1981; FIÚZA, 1983; CASTRO et al., 1994). The area can be divided into three geomorphologic zones (MCCLAIN et al., 1986; TENORE et al., 1995), which show differences in biogeochemistry (Fig. 1).

Zone I, from Cape Finisterre to Cape Peñas, is characterized by the prevalence of the colder branches of ENACW (Ríos et al., 1992) in the upwelled waters. To the East of Cape Ortegal, the coast has a zonal orientation and upwelling is favoured only by easterly winds (BOTAS et al., 1989). To the West of Cape Ortegal, upwelling is favoured under different wind conditions due to the abrupt change in coastal orientation around Cape Finisterre, the boundary between the northern and southern coast (zones I and II, respectively). This is a very open area, where the abundant coastal indentations, known as the "Rías Altas", have a minimal effect on the hydrography (TENORE et al., 1995).

Zone II, comprises the continental shelf off the "Rías Baixas", four large coastal embayments fertilized by upwelling (Rosón et al., 1995), where an intensive mussel raft culture occurs (TENORE et al., 1982, BLANTON et al., 1987). Mussel harvesting favours detritus sedimentation and formation of dissolved organic matter (DOM) (ÁlVAREZ-SALGADO et al., 1996). In addition, the Rías export organic matter in the shelfward surface flow (PREGo, 1993). Pelagic sediments off the Rías Baixas show an organic matter content usually $>8 \%$ (LóPEZ-JAMAR et al., 1992) and C/N ratios $>12$ (TENORE et al., 1984). In contrast, the organic matter content in Zone I shelf sediments is <4\% (LÓPEZ-JAMAR et al., 1992). In zone II, either the colder or warmer branches of ENACW can upwell over the shelf depending on the intensity of the northerly winds and the hydrographic conditions.

Zone III, to the South of the River Miño (Portuguese coast), presents a coastline free of large embayments and a wider continental shelf, which is characteristic of the NW Africa upwelling system, in contrast to the narrower shelves in Oregon and Perú (CODISPOTI, 1983). The orientation of the coast, nearly longitudinal, is the most 
favoured for upwelling by northerly winds. The warmer and nutrient-poorer branches of ENACW prevail in the upwelled water (FIÚZA, 1984; Ríos et al., 1992).

\section{Analytical details}

During the GALICIA-VIII (July 84) (MourIÑO et al., 1985) and GALICIA-IX (September 86) (FRAGA et al., 1987) cruises, on board the R/V "García del Cid", casts of 5 I PVC Niskin bottles with attached reversing thermometer frames were used. During the GALICIA-XI (May 91) and GALICIA-XII (September 91) cruises, on board the $R / V$ "Investigador", hydrographic sampling was performed with a CTD SBE25 and a General Oceanics (GO) rosette with 1.7 I PVC Niskin bottles. Finally, during the MORENA-I cruise (May 93), on board the R/V "Cornide de Saavedra", a CTD Mark-III and GO rosette with 10 I PVC Niskin bottles were used.

Salinity was determined from conductivity measurements (UNESCO, 1985) using an AUTOSAL 8400A. Potential temperature, $\theta$, has been used in this work. Dissolved oxygen was analyzed by Winkler titration with potentiometric endpoint detection using a Metrohm 670 automatic titrator. Apparent oxygen utilization (in moles) is calculated using Benson and Krause's equation (UNESCO, 1986) for oxygen saturation. Seawater $\mathrm{pH}$ (NBS) was measured potentiometrically and normalized to $15^{\circ} \mathrm{C}$ as described by PÉREZ and FrAGA (1987a). Alkalinity (A) was determined by titration to $\mathrm{pH} 4.4$ with $\mathrm{HCl}$, according to the potentiometric endpoint method of PÉREZ and FRAGA (1987b). Total inorganic carbon $(\mathrm{TIC})$ and $\mathrm{CO}_{2}$ pressure $\left(\mathrm{pCO}_{2}\right)$ were obtained from $\mathrm{pH}$ and alkalinity measurements by means of the equations of the inorganic carbon system, the ionization constants of MEHRBACH et al. (1973), and the $\mathrm{CO}_{2}$ solubility constant of WEISS (1974). Nutrients were determined on board by segmented flow analysis with Technicon AAll systems following HANSEN and GRASSHOFF (1983) with some modifications (MOURIÑO and FRAGA, 1985; ÁlVAREZ-SALGADO et al., 1992). Chlorophylla was measured after $90 \%$ acetone extraction using a Turner Designs Model $10.000 \mathrm{R}$ fluorometer (YENTSCH and MENZEL, 1963). 


\section{Estimation of nutrient enrichment by secondary recycling. Simple mixing model}

Nutrient enrichment by secondary recycling was estimated using a simple mixing model that allows in situ mineralized nutrients to be distinguished from those advected from the ocean. Fig. 2(a) shows the $\theta$-S diagrams for stn. 56 and 57 (on the shelf) and stn. 55 (the oceanic reference) off the River Douro during the MORENA-I cruise (Fig. 3). ENACW with $13.5^{\circ} \mathrm{C}$ and $35.9 \mathrm{psu}\left(\gamma_{\theta}=27.0\right)$ clearly upwells on the shelf. The trace of in situ mineralization can be observed when comparing the oxygen vs. temperature [Fig. 2(b)] and silicate vs. temperature [Fig. 2(c)] plots for the shelf and oceanic stations. Mineralization is maximum in shelf bottom waters and decreases upwards throughout the layer where apparent oxygen utilization (AOU) is positive. We have considered that nutrient mineralization associated with secondary recycling is nil in near surface waters with $\mathrm{AOU} \leq 0$.

In the case studied, the thermohaline properties of any sample with $A O U \geq 0$ at stn. 56 can be defined as the sum of the contribution of three endmembers [Fig. 2(a)]; the first endmember is water of $A O U=0$ at stn. 56 , the second is ENACW at stn. 55 warmer than ENACW at stn. $56\left(E N A C W_{W}\right)$, and the third endmember is ENACW at stn. 55 colder than ENACW at stn. $56\left(E^{2} A C W_{C}\right)$. As it will be shown below, a mixing triangle must be defined for each station. The contribution of the endmembers to any sample within the mixing triangle can be calculated as:

$$
\begin{gathered}
X_{W}+X_{C}+X_{O}=1 \\
\theta_{W} X_{W}+\theta_{C} X_{C}+\theta_{O} X_{O}=\theta \\
S_{W} X_{W}+S_{C} X_{C}+S_{O} X_{O}=S
\end{gathered}
$$

where,

$X_{W}, X_{C}$ and $X_{O}$ are the fractions of ENACW ${ }_{W}, E E_{C W}$ and water with $A O U=0$, respectively, in the water sample.

$\theta_{\mathrm{W}}, \theta_{\mathrm{C}}$ and $\theta_{\mathrm{O}}$ are the potential temperatures of $\mathrm{ENACW}_{\mathrm{W}}, \mathrm{ENACW}_{\mathrm{C}}$ and water with $\mathrm{AOU}=0$, respectively. 


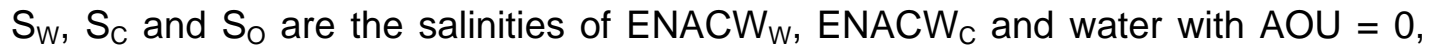
respectively.

$\theta$ and $S$ are the temperature and salinity of the sample, respectively.

The expected nutrient concentration by advection and mixing of the three endmembers, $\mathrm{Y}(\mathrm{S}, \theta)$, can be calculated in the same way by using equation 4 .

$$
Y(S, \theta)=Y_{W} X_{W}+Y_{C} X_{C}+Y_{O} X_{O}
$$

where, $Y_{W}, Y_{C}$ and $Y_{O}$ are the nutrient concentrations in $\mathrm{ENACW}_{\mathrm{W}}, \mathrm{ENACW}_{\mathrm{C}}$ and water with $\mathrm{AOU}=0$, respectively.

The model cannot rule out the influence of other endmembers and we assume that the fraction that is not accounted for by the model represents the in situ mineralized nutrient, $\mathrm{Y}_{\mathrm{M}}$, which can be simply calculated as

$$
\mathrm{Y}_{\mathrm{M}}=\mathrm{Y}-\mathrm{Y}(\mathrm{S}, \theta)
$$

where $\mathrm{Y}$ is the actual nutrient concentration in the sample.

This method cannot distinguish between diapycnic and isopycnic mixing. It is also interesting to note that the choice of the ENACW $W$ and $\mathrm{ENACW}_{\mathrm{C}}$ endmembers for each transect obviously affect the values of $X_{W}, X_{C}$ and $X_{0}$, but, mathematically, this has no effect on the final advected nutrient concentration, $Y(S, \theta)$.

The thermohaline and chemical conditions at the depth of $\mathrm{AOU}=0$ changes between stations due to the influence of surface water with different nutrient contributions from the continental margin. Regarding the oceanic endmember, large interannual variability in ENACW (PÉREZ et al., 1995) does not allow consideration of an unique oceanic reference for all cruises. In addition, clear ageing of ENACW in the open ocean off the Iberian Peninsula (PÉREZ et al., 1993) prevents the use of a single oceanic reference for each cruise. As a consequence, a mixing triangle must be defined for every station, and the $\mathrm{ENACW}_{\mathrm{W}}$ and $\mathrm{ENACW}_{\mathrm{C}}$ endmembers must be taken from an oceanic station: 1) in the same cruise; and 2) along the same radial transect than the shelf station considered. Therefore, we are assuming bidimensionality for the 
upwelling process. The oceanic reference station must be distant enough from the slope, to avoid the influence of the offshore transport of mineralized nutrients (CHAPMAN and SHANNON, 1985).

\section{Corrected chemical variables}

Ammonium and nitrite formation from organic matter oxidation requires lower oxygen consumption than nitrate. Relatively high levels of nitrite and especially ammonium, as in shelf waters of the western Iberian upwelling (see Fig. 3), affect the Redfield ratio $\left(-\Delta \mathrm{O}_{2} / \Delta \mathrm{N}\right)$ of oxygen consumption to dissolved inorganic nitrogen (DIN) production. The contribution of nitrite and ammonium is especially important in the mid water column, close to the level where $\mathrm{AOU}=0$. This effect can be quantified by using the oxygen correction $\left(\mathrm{O}_{2 \text { cor }}\right)$ introduced by Ríos et al. (1989) and FRAGA et al. (1992):

$$
\left[\mathrm{O}_{2 \mathrm{cor}}\right]=\left[\mathrm{O}_{2}\right]-0.5\left[\mathrm{NO}_{2}^{-}\right]-2\left[\mathrm{NH}_{4}^{+}\right]
$$

since 0.5 mole of oxygen is necessary to oxidize 1 mole of nitrite to nitrate and 2 moles of oxygen are required to oxidize 1 mole of ammonium to nitrate. Therefore, oxygen changes are normalized as if all the DIN produced from organic matter oxidation was in nitrate form.

On the other hand, to obtain the Redfield ratio of oxygen consumption to TIC production by organic matter oxidation $\left(-\Delta \mathrm{O}_{2} / \Delta \mathrm{C}\right)$, the influence of the dissolution/precipitation of calcium carbonate must be removed. Several authors, considering the alkalinity (SHILlER, 1981; CHEN and MILLERO, 1982; BROECKER and PENG, 1982; TAKAHASH et al., 1985), introduced the correction $0.5\left(\mathrm{~A}+\left[\mathrm{NO}_{3}{ }^{-}\right]\right)$in oceanic waters. However, in coastal waters the influence of nitrite and ammonia must also be accounted for. Only $\sim 45 \%$ of nitrite is dissociated at $\mathrm{pH}=4.4$, according to the dissociation constant of the anion, $4.4 \times 10^{-5}$ at salinity $35 \mathrm{psu}$ and temperature $20^{\circ} \mathrm{C}$ (SPENCER, 1975). Consequently, alkalinity decreases by 0.45 moles per mole of nitrite produced. On the other hand, alkalinity increases mole by mole with ammonium formation by organic matter degradation. 


$$
\left[\mathrm{TIC}_{\mathrm{cor}}\right]=[\mathrm{TIC}]-0.5 \cdot\left(\mathrm{A}+\left[\mathrm{NO}_{3}^{-}\right]+0.45 \cdot\left[\mathrm{NO}_{2}^{-}\right]-\left[\mathrm{NH}_{4}{ }^{+}\right]\right)
$$

Hereafter, corrected dissolved oxygen and corrected total inorganic carbon ( $\mathrm{TIC}_{\text {cor }}$ ) will be used.

\section{RESULTS}

\section{Nutrient ratios in source and mineralized shelf waters}

The cross-shelf section off the River Douro during the MORENA-I cruise (solid line in Fig. 1) illustrates the effect of nutrient enrichment by secondary recycling. A welldefined decrease in the oxygen concentration on the shelf [Fig. 3(b)] can be observed, with respect to oceanic water with the same thermohaline properties [Fig. 3(a)]. This relative oxygen decrease is accompanied by complementary relative increases in phosphate [Fig. 3(d)] and in $\mathrm{CO}_{2}$ partial pressure, $\mathrm{pCO}_{2}$ [Fig. 3(c)]. The latter exceeded by more than $100 \mu$ atm the pressure of equilibrium with the current atmosphere $(\sim 350$

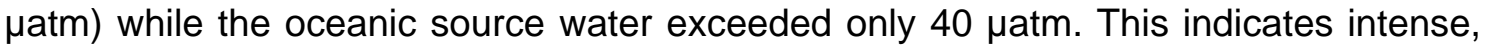
local organic matter oxidation in waters recently upwelled over the shelf, as found in other upwelling systems (FRIEDERICH and CODISPOTI, 1981; MINAS et al., 1982a; CODISPOTI, 1983, BAILEY and CHAPMAN, 1985).

Silicate also increased in shelf bottom waters with respect to source oceanic waters [Fig. 3(e)]. The distribution of silicate is closely related to that of oxygen and phosphate, as organic matter oxidation and dissolution of diatom frustules act on the same substrate: sinking and deposited POM. In this paper, the term mineralization will be used to refer to both mechanisms of nutrient regeneration.

The distributions of nitrate [Fig. 3(h)], nitrite [Fig. 3(g)] and ammonium [Fig. 3(f)] illustrate spatial differences in the pattern of nitrogen mineralization. The absence of nitrite and ammonium in the source waters confirms the in situ production of these nitrogen forms on the shelf (ROWE et al., 1975; LE BORGNE, 1978; FRIEDERICH and CODISPOTI, 1979; MINAS et al., 1982b). Nitrite and ammonium are maximal on the inner shelf and trace the instantaneous degradation of sinking POM from the subsurface 
chlorophyll-a maximum just above it (not shown). On the contrary, the maximum of nitrate (phosphate, silicate and $\mathrm{pCO}_{2}$ ) is recorded in bottom waters of the middle shelf. This would agree with the classical pattern of phytoplankton POM production in surface waters of the inner shelf, outward transport, and sinking in the middle shelf (BARBER and SMITH, 1981).

On the contrary, high nitrate and silicate levels in bottom waters off the Ría de Vigo during the GALICIA-XI cruise [Figs 4(e) and (f)] resulted from the isolation of a "cushion" of dense [Fig. 4(a)] and nutrient-rich ENACW of subpolar origin (CASTRO et al., 1994). In spite of the high surface chlorophyll-a maximum [Fig. 4(b)], mineralization occurred only just below it, which leaded to the formation of ammonium and nitrite maxima of 1.3 and $0.7 \mu \mathrm{mol} \cdot \mathrm{kg}^{-1}$, respectively [Figs $4(\mathrm{c})$ and (d)]. It seems that an "immature" early spring ecosystem had been surveyed, where massive POM sinking had not started yet.

Averaged DIN to phosphate molar ratios in the source waters, $N(S, \theta) / P(S, \theta)$, ranged from 17.0 to 18.7 for all the cruises included in this work (Table 1 ). This is the expected nitrogen:phosphorus ratio for ENACW off the Iberian Peninsula (PÉREZ et al., 1993). There is a good correlation between advected DIN and phosphate on each cruise, with correlation coefficients, $r$, always greater than 0.98 . On the other hand, the molar ratios between mineralized DIN and mineralized phosphate, $\Delta N_{M} / \Delta P_{M}$, are clearly lower, 12.2-15.0 (Table 2). Correlation between the mineralized nutrients is also high for all the cruises. The GALICIA-XI cruise has been excluded from consideration in Table 2 because of extremely low mineralization.

The averaged DIN to silicate molar ratio in the source ENACW, N(S, $\theta) / \mathrm{Si}(\mathrm{S}, \theta)$, ranged from 2.5 to 3.5 (Table 1). In contrast, the molar ratio of mineralization, $\Delta \mathrm{N}_{\mathrm{M}} / \Delta \mathrm{Si}_{\mathrm{M}}$, ranged from 1.2 to 1.5 (Table 2) for all cruises. Consequently, silicate enrichment by secondary recycling becomes greater than twice the nitrogen enrichment. The good correlation between mineralized silicate and mineralized DIN 
proves the minor contribution of particulate inorganic silica dissolution to mineralized silicate.

Carbon also undergoes this intense secondary recycling. High correlation between mineralized carbon and mineralized nitrogen $(r>0.80)$ or consumed dissolved oxygen and mineralized carbon $(r<-0.83)$ was found in all cruises. The averaged $\Delta \mathrm{C}_{\mathrm{M}} / \Delta \mathrm{N}_{\mathrm{M}}$ ratio, $\sim 8.1-9.5$ (excluding the GALICIA-VIII cruise, where ammonium was not measured), and $\Delta \mathrm{O}_{2 \mathrm{M}} / \Delta \mathrm{C}_{\mathrm{M}}$ ratio, $\sim 1.0-1.2$ (Table 2), do not agree with the direct mineralization of organic matter from phytoplankton populations, with an average $\mathrm{C} / \mathrm{N}$ molar ratio of $\sim 6-7$ and a photosynthetic quotient of $\sim 1.4$ (LAWS, 1991).

\section{Spatial pattern of secondary recycling}

As a general trend, in all cruises nutrient mineralization increased in the water column towards the bottom (Figs. 2 and 3). Therefore, to summarize the presentation of results, the bottom water sample from every station on the shelf was chosen to show the spatial pattern of secondary recycling. Silicate was the reference nutrient as it exhibits the greatest mineralization (previous section). Good correlations with the other mineralized nutrients (Table 2) allow the extrapolation of silicate observations to DIN, phosphate and TIC.

Bottom temperature increased shoreward and southward in all cruises (Fig. 5). The long-shore pattern on the outer shelf, where pure ENACW prevails, was as expected for the distribution of this water mass off the western Iberian Peninsula (Ríos et al., 1992). At the inshore stations the bottom waters tended to warm towards the south. The distributions of advected silicate, $\mathrm{Si}(\mathrm{S}, \theta)$, are inversely correlated with temperature, ranging from $1.5 \mu \mathrm{mol} \cdot \mathrm{kg}^{-1}$ at $14{ }^{\circ} \mathrm{C}$ to $4.9 \mu \mathrm{mol} \cdot \mathrm{kg}^{-1}$ at $11.2{ }^{\circ} \mathrm{C}$ (Fig. 6). The silicate mineralization pattern, $\mathrm{Si}_{\mathrm{M}}$, also shows a concomitant trend with temperature for all cruises (Fig. 7). There is an increase in the percentage of silicate mineralization in the shoreward direction, which is positively correlated to water 
temperature. In addition, the north to south increase in mineralization (zones II and III) is related to the depth-averaged chlorophyll-a distributions (Fig. 8).

During the MORENA-I cruise, the highest mineralization was found in zone III, where the shelf is wider and the upwelled nutrients are utilized on the shelf, rather than being trapped within embayments such as the Rías Baixas in zone II (PREGO, 1993). The lowest values were obtained in zone I during cruises GALICIA-VIII, -IX and -XII, where the mineralization pattern differs between cruises depending on the hydrographic situation. During GALICIA-VIII and GALICIA-IX, upwelling centres were found off Cape Finisterre and off La Coruña, respectively. Although mineralization shows a general increase shoreward, it displays a different behaviour at the upwelling centre. During GALICIA-VIII, the lowest mineralization in the area corresponded to the upwelling centre, which is attributed to POM "washout" through the large filament found off Finisterre (HAYNES et al., 1993). The opposite was found during GALICIA-IX, when the mineralization maximum was located in the upwelling centre, below the chlorophylla maximum. The presence of a poleward flowing current during the GALICIA-XII cruise (Fig. 9) is probably responsible for the enhanced silicate mineralization in the middle shelf.

Fig. 10 summarizes the average upwelled and mineralized nutrients in the three zones for all cruises. Zone I, when compared with zone II, is characterized by higher advected nutrients but lower mineralization. Nitrogen and phosphorus mineralization in zone I was about half that in zone II for all the cruises. On the other hand, zone III (surveyed only during the MORENA-I) exhibited mineralized nitrogen and phosphorus double that in zone II. The major discrepancy between zones has been found for silicate: the percentage of mineralized silicate in zone I was similar to that for DIN and phosphate, whereas it was often greater than twice these levels in zones II and III.

Changes in mineralization on a seasonal scale can be inferred from the data at zone II (surveyed in all cruises). The ratio of mineralized to advected silicate (Fig. 10) increased from $26 \%$ in May (MORENA-I), to 38\% in July-August (GALICIA-VIII) and to 
75-81 \% in September (GALICIA-IX and GALICIA-XII). During the other spring cruise (GALICIA-XI) very low nutrient enrichment by secondary recycling was found $(<10 \%)$. The same seasonal trend could also be observed in zone I (Fig. 10).

Finally, considering the budgets in Fig. 10 (averaged over shelf waters with AOU $>0$ ), nutrient accumulation extends to the most oxidized nitrogen form, nitrate. Ammonium represented $<20 \%$ of mineralized nitrogen for all cruises, except for zone II during the GALICIA-IX, when it was $58 \%$ of the mineralized DIN.

\section{DISCUSSION}

Ratios of mineralized DIN to phosphate, $\Delta \mathrm{N}_{\mathrm{M}} / \Delta \mathrm{P}_{\mathrm{M}}$, lower than comparable ratios in the source waters, $\mathrm{N}(\mathrm{S}, \theta) / \mathrm{P}(\mathrm{S}, \theta)$, have been observed in other upwelling systems. Values of $\Delta N_{M} / \Delta P_{M}$ ranging from 8 to 11 were obtained in waters off NW and SW Africa

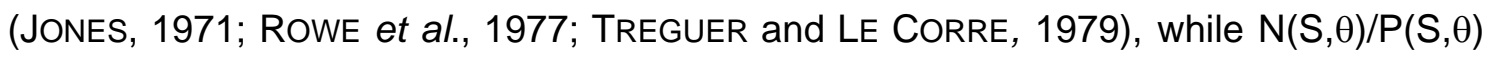
were -14-17 (MINAS et al., 1982b; BAILEY and CHAPMAN, 1985). In our case, the decrease in the source to mineralized N/P ratios are not so extreme. Longer recycling times of nitrogen compared to phosphorus have been reported in the literature (HARRISON, 1980; GARBER, 1984; BAILEY and ChAPMAN, 1985). This leads to low $\Delta N_{M} / \Delta P_{M}$ ratios, if the short residence time of organic matter in the lower water column prevents complete organic nitrogen oxidation compared to phosphorus oxidation. This can be the case in coastal waters affected by wind-driven upwelling. The alternative hypothesis of phosphorus release from interstitial waters by processes independent of organic matter oxidation (SUESS, 1981) is not supported by the intercept of mineralized nitrogen to phosphorus regression lines, which are not statistically different from zero (Table 2). During the GALICIA-XII cruise, such intercept was significant $(p<0.01)$, but as low as $0.03 \mu \mathrm{mol} \cdot \mathrm{kg}^{-1}(=0.5 / 14)$ of phosphate. Denitrification in sediments would also lower the $\Delta N_{M} / \Delta P_{M}$ ratio. However, DIN formation is well correlated with dissolved oxygen consumption, $r<-0.89$ (Table 2), and the $-\Delta \mathrm{O}_{2 \mathrm{M}} / \Delta \mathrm{N}_{\mathrm{M}}$ molar ratios are $\sim 9.5-10.5$ 
(excluding the GALICIA-VIII cruise, where ammonium was not measured), as expected when dissolved oxygen oxidizes organic matter (TAKAHASHI et al., 1985; MINSTER and BoULAHDID, 1987). This means that the sediments do not act as a major sink for available nitrogen. The western Iberian shelf behaves as the NW African shelf, where denitrification is insignificant as shelf waters are well oxygenated. This is in contrast to SW Africa and Peru (FrIEDERICH and CODISPOTI, 1979). Low ammonium in bottom waters implies strong nitrification processes, probably from ammonium released from the sediments (Rowe et al., 1975; WHITLEDGE, 1981; BARBER and SMITH, 1981). Ammonium is not an important nitrogen source either in the upwelling areas off Washington and Oregon (JAWED, 1973), at about the same latitude as the NW Iberian upwelling. On the contrary, higher ammonium levels have been measured in the inner shelf off NW Africa (CODISPOTI and FRIEDERICH, 1978; Le BORGNE, 1978; MiNAS et al., 1982b).

The shorter residence time of biogenic silica with respect to nitrogen in the photic layer (REDFIELD et al., 1963; BROECKER and PENG, 1982), favours silicate enrichment of ENACW during ageing in the open ocean (PÉREZ et al., 1993). The same 'differential-sinking' process selectively concentrates particulate silica in the lower water column and at the pelagic sediments on the shelf, leading to further silicate enrichment of upwelled ENACW. Rapid silicate dissolution leads to the low $\Delta N_{M} / \Delta \mathrm{Si}_{\mathrm{M}}$ ratios observed (Table 2$)$. Low values (0.60 to 0.95$)$ were also obtained in NW Africa (Friederich and Codispoti, 1979; Rowe et al., 1977; TREguer and Le CorRe, 1979) where the average $\mathrm{N}(\mathrm{S}, \theta) / \mathrm{Si}(\mathrm{S}, \theta)$ ratio is 2.6 (FRIEDERICH and CODISPOTI, 1979). Off SW Africa, $\Delta \mathrm{N}_{\mathrm{M}} / \Delta \mathrm{Si}_{\mathrm{M}}$ ranges from 0.26 to 0.45 , with a mean $\mathrm{N}(\mathrm{S}, \theta) / \mathrm{Si}(\mathrm{S}, \theta)$ ratio of 1.3 (BAILEY AND CHAPMAN, 1985).

Our average high $\Delta \mathrm{C}_{\mathrm{M}} / \Delta \mathrm{N}_{\mathrm{M}}$ and low $\Delta \mathrm{O}_{2 \mathrm{M}} / \Delta \mathrm{C}_{\mathrm{M}}$ ratios (Table 2) could imply a changing oxygen utilisation per mole of mineralized organic carbon down the water column. Thus, a preferential oxidation of labile protein material (higher oxygen utilisation) in the upper mineralization layer, and, consequently, the oxidation of 
carbohydrates and lipids close to the bottom (lower oxygen utilisation), would tend to modify the $\Delta \mathrm{C}_{M} / \Delta \mathrm{N}_{M}$ and $\Delta \mathrm{O}_{2 M} / \Delta \mathrm{C}_{\mathrm{M}}$ ratios as observed. These ratios could also be a consequence of the bacterial production of nitrogen-rich molecules using excess carbohydrates as energy source. This implies a relative decrease of $N_{M}$ and increase of $\mathrm{C}_{\mathrm{M}}$ without any change in $\mathrm{O}_{2 \mathrm{M}}$. On the other hand, $\mathrm{C} / \mathrm{N}$ incorporation ratios by phytoplankton populations higher than the classical Redfield value of 6.6 (SAMBROTTO et al., 1993), would also lead to high $\Delta C_{M} / \Delta N_{M}$ ratios by oxidation of such a POM in the lower layer. In addition, DOM with high C/N ratios (JACKSON and WILLIAMS, 1985), may also contribute to oxygen consumption in the lower layer (TOGGWEILER, 1989). However, downward transport of labile DOM is only important during winter mixing (COPIN-MONTÉGUT and AVRIL, 1993) by contrast to the continuous sinking of POM. Further work is necessary to relate the relative importance of every process above to the behaviour observed from our hydrographic data set.

The spatial distribution of secondary recycling in the Western Iberian shelf agrees with patterns found in upwelling areas and other coastal margins. Increasing mineralization down through the water column verifies the importance of bottom waters and/or pelagic sediments in nutrient regeneration (VAL KLUMP and MARTENS, 1983; CODISPOTI, 1983; BAILEY and CHAPMAN, 1985). Mineralization in sediments can be important, especially in areas with organically rich-sediments or large populations of benthic organisms (WHITLEDGE, 1981) as occurs off the Rías Baixas (LóPEZ-JAMAR et al., 1992). The increasing mineralization in the shoreward direction, inversely related to water depth and directly to temperature, has also been described in other areas (Christensen and PACKARD, 1977; WhitLedge, 1981; BAiley and ChAPMAN, 1985, FALKOWSKI et al., 1988).

Spatial differences are the most conspicuous characteristic of the area. Increasing mineralization from north to south is observed. To the south of the River Miño, where the shelf is wider, residence time of the shelf water is longer. The classical 
pattern of POM production on the inner shelf, then seaward transport, sinking, and subsequent bottom mineralization on the middle shelf (BARBER and SMITH, 1981) is observed. This could explain the maximum mineralization observed in the middle shelf off Portugal (Fig. 7). This must be the zone where the relevance of oxidation relative to export is greater. Unfortunately, there are neither data for primary production nor organic matter content of pelagic sediments to support this hypothesis.

In Zone II, the Rías Baixas reduce the potential mineralization on the shelf by trapping upwelled nutrients. The Ría de Vigo exports $1 / 3$ of the annual net community production (PREGo, 1993). ÁlVAREZ-SALGADO et al. (1996) reported that $\sim 2 / 3$ of the outgoing organic matter from the Ría de Arousa is new DOM. Consequently, the Rías Baixas return as potentially sinking POM a small fraction of the imported nutrients, although far enough to increase shelf mineralization regarding zone I (Rías Altas). The Rías Baixas may enhance nutrient enrichment by secondary recycling through two indirect mechanisms: 1) freshwater flowing out of these embayments increases the stratification (TENORE et al., 1995), favouring phytoplankton growth and sedimentation rates over the shelf; and 2) the important outflow of new DOM, in addition to nutrients which have not been trapped, also enhances primary production.-The good agreement between depth-averaged chlorophyll-a (Fig. 8) and silicate mineralization (Fig. 7) indicate that mineralization over the shelf is directly affected by in situ primary production (CHRISTENSEN and PACKARD, 1977).

On the contrary, the Rías Altas do not play an important role in mineralization to the north of Cape Finisterre. Stronger water turbulence and currents in this more open area (shorter residence time of the shelf water) favour export to the adjacent ocean instead of in situ oxidation, leading to the lowest mineralization in the whole Iberian upwelling system. Although the mineralization pattern shows a general increase shoreward, it displays a different behaviour at the upwelling centre. Cape Finisterre is an area of intense upwelling (FRAGA, 1981) where large filaments develop (HAYNES et al., 1993) and organic matter export across the shelf-edge is enhanced. Low levels of 
organic matter in pelagic sediments, <4\% (LÓPEZ-JAMAR et al., 1992), support this hypothesis of intensified export relative to mineralization. The contrasting situation surveyed during the GALICIA-IX cruise, corresponded to the transition from upwellingfavoured to downwelling-favoured winds, late in September. Offshore export was prevented by the presence of an oceanic anticyclonic eddy off the northern coast (CASTRO et al., in press). The large differences in silicate mineralization north and south of Cape Finisterre, probably arises from larger opal deposits to the south. A similar pattern is found off SW Africa. Cape Peninsula is the boundary between a zone of enhanced primary production and POM deposition in the north (organic matter in sediments $>5 \%$ ) and a zone of lower recycling in the east (organic matter content $<2 \%$, associated with the conditions generated by the upwelling centre around the cape (BAILEY, 1985).

In spite of the great contrast among the three zones, secondary recycling dampens the spatial differences introduced by the upwelled nutrients in the primary productivity calculated from the nutrient field (BARBER and SMITH, 1981). On the other hand, the pattern of increasing mineralization from May to October reduces the impact of seasonal change observed in source waters and, consequently in upwelled nutrients (Ríos et al., 1992). This phenomenon was also observed at a fixed station off the Rías Baixas in 1989 (ÁlvAREZ-SALGADO et al., 1993). Secondary recycling could increase phytoplankton production from $12 \%$ (zone II, MORENA-I) to $46 \%$ (zone II, GALICIA-XII) assuming the phytoplankton were nitrogen limited. For a silicon limited ecosystem, phytoplankton production would increase from 13\% (zone I, GALICIA-VIII) to $81 \%$ (zone II, GALICIA-XII).

\section{CONCLUSIONS}

A simple mixing model has been used to asses the spatial pattern of nutrient accumulation by secondary recycling on shelf waters of the NW Iberian upwelling system. As in other coastal margins, topography, hydrodynamics and continental 
outwelling control the observed pattern. Temporal and spatial variability of mineralized nutrients show the importance of in situ oxidation relative to export across the shelfedge. In this sense, the percentages of mineralized nutrients represent the fraction of biogenic matter exportable from the photic layer which is mineralised over the shelf, and where (when) nutrient accumulation by secondary recycling is a relevant process, export should be prevented.

Secondary recycling increases the potential primary production in the photic zone. The ratio of new to total production will be lower when the whole water column over the shelf (regenerated production =primary+secondary recycling) instead of only the photic zone (regenerated production =primary recycling) is considered. In addition, productivity via secondary recycling is supported mainly by mineralized nitrate, which differs from the classical idea of regenerated production expected via ammonium+urea and new production via nitrate (EPPLEY and PETERSON, 1979). Consequently, where secondary recycling is a relevant process, ${ }^{15} \mathrm{~N}$-based calculations of the EPPLEY and PETERSON'S ' $f_{\text {RATIO' }}$ would overestimate the real new to regenerated production ratio, when the whole water column is considered.

Nutrient accumulation by secondary recycling dampens the temporal and spatial variability in nutrient conditions when they are driven by upwelling. Off the NW Iberian Peninsula a complete upwelling cycle lasts 1-2 weeks (BLANTON et al., 1984; Álvarez-SALGADO et al., 1993), the same time-scale as a complete secondary recycling event, which helps to maintain high nutrient concentrations between upwelling pulses. The role played by the Rías Baixas in the secondary recycling pattern must be examined more closely. They act as nutrient-traps, reducing the potential mineralization on the shelf. On the other hand, their out-flowing fresh surface-waters increase stratification and favour phytoplankton growth and sedimentation over the shelf. Their export of new DOM enhances primary production.

As the main source of new nutrients in upwelling areas is sub-surface oceanic water, nutrient ratios in these source waters could determine the element that limits 
primary production. However, different mineralization rates do modify these ratios and, in turn, affect the species composition of the phytoplankton community (LEVASSEUR and THERRIAULT, 1987). Changes in nutrient ratios between source and mineralized waters indicate an increasing enrichment of mineralized nutrients from silicate $>$ phosphate $>$ DIN, as usually found in other upwelling systems. In addition, silicate enrichment increases where larger biogenic deposits are present. The development of diatomdominated phytoplankton assemblages could be favoured.

This work provides initial findings about nutrient cycling in this little studied region. We hope that our results help forthcoming 'process orientated' studies (sizefractionated phytoplankton primary production, microzooplankton grazing/respiration, sinking/sedimentation rates, bacterial activity, etc...), necessary to better understand nutrient biogeochemistry in the NW Iberian upwelling system.

Acknowledgments. The authors wish to thank all the participants in the GALICIA-VIII, GALICIA-IX, GALICIA-XI, GALICIA-XII and MORENA-I cruises for their unconditional devotion. We are also very grateful to the crews of the R/V "García del Cid", "Investigador S." and "Cornide de Saavedra", who were always just ready to help us. Special thanks to Ramón Penín for his help in drawing the figures. We are very grateful to Stuart W. Gibb and Andy P. Rees for their editorial comments. Valuable criticisms by three anonymous reviewers are greatly appreciated. Support for this work came from EU projects contract No. MAST-CT90-0017 and MAS2-CT93-0065. 


\section{REFERENCES}

Álvarez-Salgado, X.A., Pérez F.F. and Fraga, F. (1992) Determination of nutrient salts by automatic methods both in seawater and brackish water: the phosphate blank. Marine Chemistry, 39, 311-319.

Álvarez-Salgado, X.A., Rosón, G., Pérez, F.F. and Pazos, Y. (1993) Hydrographic variability off the Rías Baixas (NW Spain) during the upwelling season. Journal of Geophysical Research, 98(C8), 14447-14455.

Álvarez-Salgado, X.A., Rosón, G., Pérez, F.F., Figueiras, F.G. and Pazos, Y. (1996) Nitrogen cycling in an estuarine upwelling system, the Ría de Arousa (NW Spain). I: short-time-scale evolution of hydrodynamic and biogeochemical circulation of nitrogen species. Marine Ecology Progress Series, 135, 259-273.

Bailey, G.W. (1985) Distribution and cycling of nutrients at four sites in the Benguela system. In: International Symposium on the most important Upwelling Areas of Western Africa, vol. 1, Instituto de Investigaciones Pesqueras, Barcelona, pp. 305317.

Bailey, G.W. and Chapman, P. (1985) The nutrient status of the St. Helena Bay region in February 1979. In: South African Ocean Colour and Upwelling Experiment, L.V. Shannon, editor, Sea Fisheries Research Institute, Cape Town, pp. 125-145.

Barber, R.T. and Smith, R.L. (1981) Coastal upwelling ecosystems. in: Analysis of marine systems, A.R. Longhurst, editor, Academic Press, San Diego, pp. 31-68.

Biscaye, P.E., Flagg, C.N. and Falkowski, P.G. (1994) The Shelf Edge Exchange Processes experiment, SEEP-II: an introduction to hypothesis, results and conclusions. Deep-Sea Research, part II, 41, 231-252.

Blanton, J.O., Atkinson, L.P., Castillejo, F.F. and Lavín, A. (1984) Coastal upwelling off the Rías Bajas, Galicia, Northwest Spain, I: hydrographic studies. Rapports et Procès-verbeaux des Rèunions Conseil International pour l'Exploration de la mer, 183, 79-90. 
Blanton, J.O., Tenore, K.R., Castillejo, F.F., Atkinson, L.P., Schwing, F.B. and Lavín, A. (1987) The relationship of upwelling to mussel production in the rías on the western coast of Spain. Journal of Marine Research, 45, 497-511.

Botas, J.A., Fernández, E., Bode, A. and Anadón, R. (1989) Water masses off the Central Cantabrian Coast. Scientia Marina, 53, 775-761.

Broecker, W.S. and Peng, T.-H (1982) Tracers in the Sea, Eldigio Press, New York, $690 \mathrm{pp}$.

Castro, C.G., Álvarez-Salgado, X.A., Figueiras, F.G., Pérez, F.F. and Fraga, F. (in press) Transient hydrographic and chemical conditions affecting microplankton populations in the coastal transition zone of the Iberian upwelling system (NW Spain) in September 1986. Journal of Marine Research, 55

Castro, C.G., Pérez, F.F., Álvarez-Salgado, X.A., Rosón, G. and Ríos, A.F. (1994) Hydrographic conditions associated with the relaxation of an upwelling event off the Galician Coast (NW Spain). Journal of Geophysical Research, 99, 5135-5147.

Chapman, P. and Shannon, L.V. (1985) The Benguela ecosystem, Part II. Chemistry and related processes. Oceanography and Marine Biology Annual Reviews, 23, 183251.

Chen, C.-T.A. and Millero, F.J. (1982) Comment on calculating the oceanic $\mathrm{CO}_{2}$ increase: a need for caution by A.M. Shiller. Journal of Geophysical Research, 87(C3), 2083-2085.

Christensen, J.P. and Packard, T.T. (1977) Sediment metabolism for the northwest Africa upwelling system. Deep-Sea Research, 24, 331-343.

Codispoti, L.A. (1983) Nitrogen in upwelling systems. In: Nitrogen in the marine environment, E.J. Carpenter and D.G. Capone, editors, Academic Press, New York, pp. 513-564.

Codispoti, L.A. and Friederich, G.E. (1978) Local and mesoscale influences on nutrient variability in the northwest African upwelling region near Cabo Corbeiro. Deep-Sea Research, 25, 751-770. 
Copin-Montégut, G. and Avril, B. (1993) Vertical distribution and temporal variation of dissolved organic carbon in the North-Western Mediterranean Sea. Deep-Sea Research, 40, 1963-1972.

Dugdale, R.C. and Goering, J.J. (1967) Uptake of new and regenerated forms of nitrogen in primary production. Limnology and Oceanography, 12, 196-206.

Eppley, R.W. and Peterson, B.J. (1979) Particulate organic matter flux and planktonic new production in the deep ocean. Nature, 282, 677-680.

Falkowski, P.G., Flagg, C.N., Rowe, G.T., Smith, S.L., Whitledge, T.E. and Wirick, C.D. (1988) The fate of a spring phytoplankton bloom: export or oxidation?. Continental Shelf Research, 8, 457-484.

Fiúza, A.F.G. (1983) Upwelling patterns off Portugal. In: Coastal upwelling, E. Suess and J. Thiede, editors, Plenum, London, pp. 85-98.

Fiúza, A.F.G. (1984) Hidrologia e dinamica das augas costeiras de Portugal. Doctoral Thesis, University of Lisbon, Portugal, 294 pp.

Fraga, F., Figueiras, F.G., Prego, P., Pérez, F.F. and Ríos, A.F. (1987) Campaña "Galicia IX" oceánica. In: Datos informativos del Instituto de Investigaciones Pesqueras, vol. 20, Instituto de Investigaciones Marinas, Vigo, 148 pp.

Fraga, F., Pérez, F.F., Figueiras, F.G. and Ríos, A.F. (1992) Stoichiometric variations of $\mathrm{N}, \mathrm{P}, \mathrm{C}$, and $\mathrm{O}_{2}$ during a Gymnodinium catenatum red tide and their interpretation. Marine Ecology Progress Series, 87, 123-134.

Fraga, F. (1981) Upwelling off the Galician Coast, Northwest Spain. In: Coastal Upwelling Series, vol. 1, F.A. Richards, editor, AGU, Washington D.C., pp. 176-182.

Friederich, G.E. and Codispoti, L.A. (1979) On some factors influencing dissolved silica distribution over the northwest African shelf. Journal of Marine Research, 37, 337353.

Friederich, G.E. and Codispoti, L.A. (1981) The effect of mixing and regeneration on the nutrient content of upwelling waters of Perú. In: Coastal Upwelling Series, vol. 1, F.A. Richards, editor, AGU, Washington, D.C., pp. 221-227. 
Garber, J.H. (1984) Laboratory study of nitrogen and phosphorus remineralization during the decomposition of coastal plankton and seston. Estuarine Coastal shelf Science, 18, 685-702.

Hansen, H.P. and Grasshoff, K. (1983) Automated chemical analysis. In: Methods of seawater analysis, 2nd Edition, K. Grasshoff, M. Ehrhardt and K. Kermling, editors, Verlag Chemie, Wheinheim, pp. 347-395.

Haynes, R., Barton, E.D. and Pilling, I. (1993) Development, persistence and variability of upwelling filaments off the Atlantic Coast of the Iberian Peninsula. Journal of Geophysical Research, 98, 22681-22692.

Harrison, W.G. (1980) Nutrient regeneration and primary production in the sea. In: Primary Productivity in the Sea, P.G. Falkowski, editor, Plenum Press, New York, pp. $433-460$

Jackson, G.A. and Williams, P.M. (1985) Importance of dissolved organic nitrogen and phosphorus to biological nutrient cycling. Deep-Sea Research, 32, 223-235.

Jawed, M. (1973) Ammonia excretion by zooplankton and its significance to primary production during summer. Marine Biology, 23, 115-120.

Jones, P.G.W. (1971) the Southern Benguela Current region in February, 1966: Part. I. Chemical observations with particular reference to upwelling. Deep-Sea Research, 18, $193-208$.

Laws, E. (1991) Photosynthetic quotients, new production and net community production in the open ocean. Deep-Sea Research, 38, 143-167.

Le Borgne, R.P. (1978) Ammonium formation in Cape Timiris (Mauritania) upwelling. Journal of experimental marine Biology and Ecology, 31, 253-265.

Levasseur, M.E. and Therriault, J.-C. (1987) Phytoplankton biomass and nutrient dynamics in a tidally induced upwelling: the role of the $\mathrm{NO}_{3}: \mathrm{SiO}_{4}$ ratio. Marine Ecology Progress Series, 39, 87-97. 
López-Jamar, E., Cal, R.M., González, G., Hanson, R.B., Rey, J., Santiago, G., Tenore, K.R. (1992) Upwelling and outwelling effects on the benthic regime of the continental shelf off Galicia, NW Spain. Journal Marine Research, 50, 465-488.

Mantoura, R.F.C., Martin, J.-M. and Wollast, R. (1991) Introduction. In: Ocean Margin Processes in Global Change, R.F.C. Mantoura, J.-M. Martin and R. Wollast, editors, Wiley and Sons, Chichester, pp. 1-3.

McClain, C.R., Chao, S.-Y., Atkinson, L.P., Blanton, J.O. and de Castillejo, F.F. (1986) Wind-driven upwelling in the vicinity of Cape Finisterre, Spain. Journal of Geophysical Research, 91, 8470-8486.

Mehrbach, C., Culberson, C.H., Hawley, J.E. and Pytkowitcz, R.M. (1973) Measurements of the apparent dissociation constants of carbonic acid in seawater at atmospheric pressure, Limnology and Oceanography, 18, 897-906.

Minas, H.J., Packard, T.T., Minas, M. and Coste, B. (1982a) An analysis of the production-regeneration system in the coastal upwelling area off NW Africa based on oxygen, nitrate and ammonium distributions. Journal of Marine Research, 40, 615641.

Minas, H.J., Codispoti, L.A. and Dugdale, R.C. (1982b) Nutrients and primary production in the upwelling region off Northwest Africa. Rapports et Procès-verbeaux des Rèunions Conseil International pour l'Exploration de la mer, 180, 148-183.

Minas, H.J., Minas, M. and Packard, T.T. (1986) Productivity in upwelling areas deduced from hydrographic and chemical fields. Limnology and Oceanography, 31, 1182-1206.

Minster, J.-F. and Boulahdid, M. (1987) Redfield ratios along isopycnal surfaces-a complementary study. Deep-Sea Research, 34, 1981-2003.

Moisan, J.R. (1994) Modeling nutrient and plankton processes in the California coastal transition zone. Oceanography, 7, 61-62.

Monteiro, J.H., Abrantes, F.G., Alveirinho-Días, J.M. and Gaspar, L.C. (1983) Upwelling records in recent sediments from southern Portugal: a reconnaissance 
survey. In: Coastal upwelling, E. Suess and J. Thiede, editors, Plenum, London, pp. 145-162.

Mouriño, C., Pérez, F.F., Ríos, A.F., Manríquez, M., Estrada, M., Marrasé, C., Prego, R. and Fraga, F. (1985) Campaña "Galicia VIII" datos básicos. In: Datos informativos del Instituto de Investigaciones Pesqueras, vol. 13, Instituto de Investigaciones Marinas, Vigo, 108 pp.

Mouriño, C. and Fraga, F. (1985) Determinación de nitratos en agua de mar. Investigación Pesquera, 49, 81-96.

Pérez, F.F. and Fraga, F. (1987a) The pH measurements in seawater on NBS scale. Marine Chemistry, 21, 315-327.

Pérez, F.F. and Fraga, F. (1987b) A precise and rapid analytical procedure for alkalinity determinations. Marine Chemistry, 21, 169-182.

Pérez, F.F., Mouriño, C., Fraga, F. and Ríos, A.F (1993) Displacement of water masses and remineralization rates off the Iberian Peninsula by nutrient anomalies. Journal of Marine Research, 51, 869-892.

Pérez, F.F., Ríos, A.F., King, B.A. and Pollard, R. (1995) Decadal changes of the $\theta$-S relationship of the Eastern North Atlantic Central Water. Deep-Sea Research, 42 , 1849-1864.

Prego, R. (1993) General aspects of carbon biogeochemistry in the Ría de Vigo, northwestern Spain. Geochimia Cosmochimia Acta, 57, 2041-2052.

Redfield, A.C., Ketchum, B.H. and Richards, F.A. (1963) The influence of organisms on the composition of sea-water. In: The Sea, vol. 2, M.N. Hill, editor, Wiley and Sons, pp. 26-77.

Ríos, A.F., Fraga, F. and Pérez, F.F. (1989) Estimation of coefficients for the calculation of "NO", "PO" and "CO", starting from the elemental composition of natural phytoplankton. Scientia Marina, 53, 779-784.

Ríos, A.F., Pérez, F.F. and Fraga, F. (1992) Water masses in the upper and middle North Atlantic Ocean east of the Azores. Deep-Sea Research, 39, 645-658. 
Rosón, G., Pérez, F.F., Álvarez-Salgado, X.A. and Figueiras, F.G. (1995) Variation of both thermohaline and chemical properties in an estuarine upwelling ecosystem: Ría de Arousa. I. Time Evolution. Estuarine Coastal shelf Science, 41, 195-213.

Rowe, G.T., Clifford, C.H., Smith Jr., K.L. and Hamilton, P.L. (1975) Benthic nutrient regeneration and its coupling to primary productivity in coastal waters. Nature, 255, 215-217.

Rowe, G.T., Clifford, C.H., Smith Jr., K.L. and Hamilton, P.L. (1977) Regeneration of nutrients in sediments off Cape Blanc, Spanish Sahara. Deep-Sea Research, 24, 5764.

Sambrotto, R.N., Savidge, G., Robinson, C., Boyd, P., Takahashi, T., Karl, D.M., Langdon, C., Chipman, D., Marra, J. and Codispoti, L. (1993) Elevated consumption of carbon relative to nitrogen in the surface ocean. Nature, 363 (6426), 248-250.

Shiller, A.M. (1981) Calculating the oceanic $\mathrm{CO}_{2}$ increase: a need for caution. Journal of Geophysical Research, 86 (C11), 11083-11088.

Spencer, C.P. (1975) The micronutrient elements. In: Chemical Oceanography, 2nd Edition, J.P. Riley and G. Skirrow, editors, Academic Press, London, pp. 245-300.

Suess, E. (1981) Phosphate regeneration from sediments of the Perú continental margin by dissolution of fish debris. Geochimia Cosmochimia Acta, 45, 577-588.

Takahashi, T., Broecker, W.S. and Langer, S. (1985) Redfield ratio based on chemical data from isopycnal surfaces. Journal of Geophysical Research, 90, 6907-6924.

Tenore, K.R. plus 14 authors (1982) Coastal upwelling in the Rías Baixas, NW Spain. Contrasting the benthic regimes of the Ría de Arousa and Muros. Journal of Marine Research, 40, 701-772.

Tenore, K.R., Cal, R.M., Hanson, R.B., López-Jamar, E., Santiago, G. and Tietjen, J.H. (1984) Coastal upwelling off the Rías Bajas, Galicia, Northwest Spain, II: benthic studies. Rapports et Procès-verbeaux des Rèunions Conseil International pour l'Exploration de la mer, 183, 91-100. 
Tenore, K.R. plus 18 authors (1995) Fisheries and Oceanography off Galicia, NW Spain: Mesoscale spatial and temporal changes in physical processes and resultant patterns of biological productivity. Journal of Geophysical Research, 100, 1094310966.

Toggweiler, J.R. (1989) Is the downward dissolved organic matter (DOM) flux important in carbon transport?. In: Productivity of the ocean: present and past, W.H. Berger, V.S. Smetacek and G. Wefer, editors, J. Wiley \& Sons, pp. 65-83.

Treguer, P. and Le Corre, P. (1979) The ratios of nitrate, phosphate and silicate during uptake and regeneration phases of the Moroccan upwelling regime. Deep-Sea Research, 26, 163-184.

UNESCO (1985) The international system of units (SI) in oceanography. UNESCO technical papers in marine sciences, 45.

UNESCO (1986). Progress on oceanographic tables and standards 1983-1986. Work and recommendations of the UNESCO/SCOR/ICES/IAPSO Joint Panel. UNESCO technical papers in marine sciences, $\mathbf{5 0}$.

Val Klump, J. and Martens, C.S. (1983) Benthic nitrogen regeneration. In: Nitrogen in the marine environment, E.J. Carpenter and D.G. Capone, editors, Academic Press, New York, pp. 411-457.

Walsh, J.J., Rowe, G.T., Iverson, R.L. and McRoy, C.P. (1981) Biological export of shelf carbon: a neglected sink of the global $\mathrm{CO}_{2}$ cycle. Nature, 291, 196-201.

Walsh, J.J. (1989) How much shelf production reaches the deep sea?. In: Productivity of the ocean: present and past, W.H. Berger et al., editors, John Wiley, New York, pp. $175-191$.

Walsh, J.J. (1991) Importance of continental margins in the marine biogeochemical cycling of carbon and nitrogen. Nature, 359, 53-55.

Weis, R.F. (1974) Carbon dioxide in water and seawater: the solubility of a non-ideal gas. Marine Chemistry, 2, 203-215. 
Whitledge, T.E. (1981) Nitrogen recycling and biological populations in upwelling ecosystems. In: Coastal Upwelling Series, vol. 1, F.A. Richards, editor, AGU, Washington D.C., pp. 257-273.

Wroblewski, J.S. and Hoffmann, E.E. (1989) U.S. interdisciplinary modeling studies of coastal-offshore exchange processes: past and future. Progress in Oceanography, 23, 65-99.

Yentsch, C. and Menzel, W. (1963) A method for the determination of phytoplankton, chlorophyll and phaeopigments by fluorescence, Deep-Sea Research, 10, 221-231. 
Table 1. Mean $(<Y>)$, standard deviation $\left(\sigma_{y}\right)$, maximum $\left(Y_{\max }\right)$ and minimum $\left(Y_{\min }\right)$ values of the thermohaline properties $(S, \theta)$, nutrients $(N, P, S i)$ and nutrient molar ratios (N/P,N/Si) in the advected offshore ENACW for all cruises included in this study. Temperature in ${ }^{\circ} \mathrm{C}$, salinity in psu and nutrient concentrations in $\mu \mathrm{mol} \cdot \mathrm{kg}^{-1}$.

\begin{tabular}{|c|c|c|c|c|c|}
\hline & GALICIA-VIII & GALICIA-IX & GALICIA-XI & GALICIA-XII & MORENA1 \\
\hline$<\theta> \pm \sigma_{\theta}$ & $12.1 \pm 0.5$ & $12.0 \pm 0.6$ & $11.7 \pm 0.3$ & $12.8 \pm 0.4$ & $13.4 \pm 0.3$ \\
\hline$\theta \max$ & 13.2 & 13.4 & 12.5 & 13.6 & 14.1 \\
\hline$\theta \min$ & 11.1 & 11.2 & 11.2 & 11.8 & 12.5 \\
\hline$\langle S\rangle_{ \pm} \sigma_{S}$ & $35.63 \pm 0.06$ & $35.62 \pm 0.08$ & $35.64 \pm 0.03$ & $35.80 \pm 0.06$ & $35.89 \pm 0.05$ \\
\hline Smax & 35.78 & 35.78 & 35.74 & 35.92 & 36.00 \\
\hline Smin & 35.52 & 35.51 & 35.61 & 35.66 & 35.77 \\
\hline$<\mathrm{N}> \pm \sigma_{\mathrm{N}}$ & $8.4 \pm 1.4$ & $8.9 \pm 1.2$ & $9.8 \pm 0.9$ & $7.3 \pm 1.1$ & $5.4 \pm 1.6$ \\
\hline $\mathrm{N}_{\max }$ & 10.8 & 11.1 & 11.0 & 9.2 & 9.3 \\
\hline Nmin & 5.1 & 6.2 & 6.6 & 4.1 & 2.5 \\
\hline$<P> \pm \sigma_{P}$ & $0.46 \pm 0.07$ & $0.49 \pm 0.07$ & $0.56 \pm 0.06$ & $0.42 \pm 0.02$ & $0.32 \pm 0.09$ \\
\hline Pmax & 0.58 & 0.60 & 0.64 & 0.45 & 0.51 \\
\hline Pmin & 0.29 & 0.33 & 0.36 & 0.35 & 0.15 \\
\hline$<\mathrm{Si}> \pm \sigma_{\mathrm{S}}$ & $2.7 \pm 0.5$ & $2.9 \pm 0.7$ & $3.6 \pm 0.4$ & $2.9 \pm 0.7$ & $1.6 \pm 0.5$ \\
\hline Simax & 3.6 & 4.3 & 4.1 & 4.6 & 3.0 \\
\hline Simin & 1.6 & 1.7 & 2.1 & 2.0 & 0.6 \\
\hline$<\mathrm{N} / \mathrm{P}\rangle_{ \pm} \sigma_{\mathrm{N} / \mathrm{P}}$ & $18.3 \pm 0.9$ & $18 \pm 2$ & $17.7 \pm 0.4$ & $18.7 \pm 0.6$ & $17.0 \pm 0.9$ \\
\hline$(N / P)_{\max }$ & 20.5 & 23 & 18.4 & 19.9 & 19.4 \\
\hline (N/P)min & 17.2 & 16 & 17.1 & 17.7 & 15.1 \\
\hline$<\mathrm{N} / \mathrm{Si}> \pm \sigma_{\mathrm{N} / \mathrm{Si}}$ & $3.1 \pm 0.2$ & $2.9 \pm 0.3$ & $2.7 \pm 0.1$ & $2.5 \pm 0.3$ & $3.5 \pm 0.4$ \\
\hline$(\mathrm{N} / \mathrm{Si})_{\max }$ & 3.6 & 3.8 & 3.2 & 3.1 & 4.8 \\
\hline (N/Si)min & 2.8 & 2.5 & 2.5 & 1.4 & 2.8 \\
\hline
\end{tabular}


Table 2. Intercept (A), slope (B) and correlation coefficients (r) of selected linear regressions $(Y=A+B X)$ among mineralized nutrients $(C, N, P$ and Si) and with consumed dissolved oxygen $\left(\mathrm{O}_{2}\right)$ for all cruises studied. GALICIA-XI cruise are not included due to the absence of significant mineralization. Concentration values in $\mu \mathrm{mol} \cdot \mathrm{kg}^{-1} . \mathrm{ns}$, no significant; * $p<0.05,{ }^{* *} p<0.01,{ }^{* *} p<0.001$

\begin{tabular}{|c|c|c|c|c|c|}
\hline$Y$ vs. $X$ & & $\begin{array}{l}\text { GALICIA- } \\
\text { VIII" }\end{array}$ & GALICIA-IX & GALICIA-XII & MORENA-I \\
\hline \multirow{4}{*}{$\mathrm{N}_{\mathrm{M}}$ vs. $\mathrm{P}_{\mathrm{M}}$} & $\operatorname{err}_{Y}$ & \pm 0.7 & \pm 0.9 & \pm 0.6 & \pm 0.4 \\
\hline & $A \pm e r_{A}$ & $-0.2 \pm 0.1^{n s}$ & $0.0 \pm 0.1^{n s}$ & $-0.5 \pm 0.1^{\star *}$ & $0.04 \pm 0.04^{n s}$ \\
\hline & $\mathrm{B} \pm \mathrm{err}_{\mathrm{B}}$ & $12.2 \pm 0.9^{\star \star \star}$ & $15 \pm 1^{\star \star \star}$ & $14.0 \pm 0.5^{\star \star \star}$ & $14.9 \pm 0.4^{\star \star \star}$ \\
\hline & $r$ & 0.80 & 0.81 & 0.98 & 0.97 \\
\hline \multirow{4}{*}{$\mathrm{N}_{\mathrm{M}}$ vs. $\mathrm{Si}_{\mathrm{M}}$} & err $_{Y}$ & \pm 0.5 & \pm 0.9 & \pm 1.5 & \pm 0.6 \\
\hline & $\mathrm{A} \pm \mathrm{err}_{\mathrm{A}}$ & $-0.17 \pm 0.06^{n s}$ & $0.4 \pm 0.1^{\star \star *}$ & $0.2 \pm 0.1^{n s}$ & $0.04 \pm 0.08^{n s}$ \\
\hline & $\mathrm{B} \pm \mathrm{err}_{\mathrm{B}}$ & $1.21 \pm 0.06^{\star * *}$ & $1.3 \pm 0.1^{\star \star *}$ & $1.4 \pm 0.1^{\star \star *}$ & $1.54 \pm 0.07^{\star \star \star}$ \\
\hline & $r$ & 0.89 & 0.81 & 0.69 & 0.90 \\
\hline \multirow{4}{*}{$\mathrm{P}_{\mathrm{M}}$ vs. $\mathrm{Si}_{\mathrm{M}}$} & $\operatorname{err}_{Y}$ & \pm 0.06 & \pm 0.06 & \pm 0.05 & \pm 0.04 \\
\hline & $\mathrm{A} \pm \mathrm{err}_{\mathrm{A}}$ & $0.020 \pm 0.007^{\star \star \star}$ & $0.03 \pm 0.01^{\star \star *}$ & $0.04 \pm 0.09^{n s}$ & $0.03 \pm 0.005^{n s}$ \\
\hline & $\mathrm{B} \pm \mathrm{err}_{\mathrm{B}}$ & $0.096 \pm 0.006^{\star \star \star}$ & $0.089 \pm 0.008^{\star \star *}$ & $0.092 \pm 0.003^{\star \star \star}$ & $0.105 \pm 0.004^{\star \star \star}$ \\
\hline & $r$ & 0.77 & 0.79 & 0.94 & 0.93 \\
\hline \multirow{4}{*}{$\mathrm{C}_{\mathrm{M}}$ vs. $\mathrm{N}_{\mathrm{M}}$} & $\operatorname{err}_{Y}$ & \pm 10 & \pm 9 & \pm 12 & \pm 5 \\
\hline & $\mathrm{A} \pm \mathrm{err}_{\mathrm{A}}$ & $1 \pm 1^{n s}$ & $-2 \pm 1^{n s}$ & $2 \pm 2^{n s}$ & $-1.8 \pm 0.7^{n s}$ \\
\hline & $\mathrm{B} \pm \mathrm{err}_{\mathrm{B}}$ & $12 \pm 1^{\star \star \star}$ & $9.5 \pm 0.7^{\star \star *}$ & $9.0 \pm 0.5^{\star \star \star}$ & $8.1 \pm 0.4^{\star \star \star}$ \\
\hline & $r$ & 0.64 & 0.80 & 0.85 & 0.88 \\
\hline \multirow{4}{*}{$\mathrm{O}_{2 M}$ vs. $\mathrm{C}_{\mathrm{M}}$} & $\mathrm{err}_{\mathrm{Y}}$ & \pm 7 & \pm 6 & \pm 7 & \pm 8 \\
\hline & $\mathrm{A} \pm \mathrm{err}_{\mathrm{A}}$ & $-2.8 \pm 0.8^{\star \star \star}$ & $-2.8 \pm 0.9^{\star \star \star}$ & $-1 \pm 1^{n s}$ & $-4 \pm 1^{\star \star \star}$ \\
\hline & $\mathrm{B} \pm \mathrm{err}_{\mathrm{B}}$ & $-1.15 \pm 0.05^{\star \star \star}$ & $-1.00 \pm 0.04^{\star \star *}$ & $-1.18 \pm 0.03^{\star \star *}$ & $-1.15 \pm 0.07^{\star \star *}$ \\
\hline & $r$ & -0.89 & -0.93 & -0.95 & -0.83 \\
\hline \multirow{4}{*}{$\mathrm{O}_{2 M}$ vs. $\mathrm{N}_{\mathrm{M}}$} & err $_{Y}$ & \pm 7 & \pm 8 & \pm 12 & \pm 7 \\
\hline & $\mathrm{A} \pm \mathrm{err}_{\mathrm{A}}$ & $-6.6 \pm 0.8^{* \star \star}$ & $-1 \pm 1^{\text {ns }}$ & $-5 \pm 2^{* \star *}$ & $-3 \pm 1^{* \star *}$ \\
\hline & $\mathrm{B} \pm \mathrm{err}_{\mathrm{B}}$ & $-12.3 \pm 0.6^{\star \star \star}$ & $-9.5 \pm 0.6^{\star \star \star}$ & $-10.5 \pm 0.5^{\star \star \star}$ & $-9.5 \pm 0.5^{\star \star \star}$ \\
\hline & $r$ & -0.86 & -0.84 & -0.89 & -0.87 \\
\hline$\Delta \mathrm{P}: \Delta \mathrm{N}: \Delta \mathrm{C}:-\Delta \mathrm{O}$ & & 1:12:146:-150 & 1:15:141:-141 & 1:14:126.-147 & 1:15:120:-140 \\
\hline
\end{tabular}

- Ammonium was not measured during the GALICIA-VIII cruise 


\section{FIGURE CAPTIONS}

Fig. 1. Map of the survey area for the different cruises included in this work. Dark points show the position of the stations occupied on each cruise. Dashed lines represent the $200-\mathrm{m}$ isobath. Solid lines represent the cross-shelf sections used in Figs. 3 and 4. Zones I, II and III are also delimited.

Fig. 2. $\theta-\mathrm{S}$ diagram (a); oxygen versus temperature (b); and silicate versus temperature (c) for stations 55, 56 and 57, off the River Douro during the MORENAI cruise. circles, station 55; squares, station 56, triangles station 57 . Dotted line, $A O U=0$. Bold line, mixing triangle for station 57.

Fig. 3. Cross-shelf distributions off the River Douro during the MORENA-I cruise (May 1993): $\gamma_{\theta}=[\rho(\mathrm{S}, \theta, 0)-1000](\mathbf{a})$; dissolved oxygen (b); $\mathrm{pCO}_{2}$, in $\mu$ atm (c); phosphate (d); silicate (e); ammonium (f); nitrate (g); and nitrite (h). Concentrations in $\mu \mathrm{mol} \cdot \mathrm{kg}^{-1}$

Fig. 4. Cross-shelf distributions off the Ría de Vigo during the GALICIA-XI cruise (May 91): $\gamma_{\theta}=[\rho(\mathrm{S}, \theta, 0)-1000](\mathbf{a})$; chlorophyll-a (b); ammonium (c); nitrite (d); nitrate (e) and silicate (f). Concentrations in $\mu \mathrm{mol} \cdot \mathrm{kg}^{-1}$.

Fig. 5. Spatial distribution of bottom potential temperature (in ${ }^{\circ} \mathrm{C}$ ) over the shelf during MORENA-I, May 93 (a); GALICIA-VIII, July 84 (b); GALICIA-XII, September 91 (c); and GALICIA-IX, September $86(\mathbf{d})$.

Fig. 6. Spatial distribution of bottom advected silicate (in $\mu \mathrm{mol} \cdot \mathrm{kg}^{-1}$ ) over the shelf during MORENA-I, May 93 (a); GALICIA-VIII, July 84 (b); GALICIA-XII, September 91 (c); and GALICIA-IX, September 86 (d).

Fig. 7. Spatial distribution of the percentage of mineralized silicate $\left(\mathrm{Si}_{\mathrm{M}} / \mathrm{Si} \cdot 100\right)$ over the shelf during MORENA-I, May 93 (a); GALICIA-VIII, July 84 (b); GALICIA-XII, September 91 (c); and GALICIA-IX, September 86 (d).

Fig. 8. Spatial distribution of the averaged chlorophyll-a concentration over the shelf, $\int$ Chla.dz/Jdz (in $\mathrm{mg} \cdot \mathrm{m}^{-3}$ ), during MORENA-I, May 93 (a); GALICIA-VIII, July 84 (b); 
GALICIA-XII, September 91 (c); and GALICIA-IX, September 86 (d). Chla, chlorophyll-a; z, depth

Fig. 9. Spatial distribution of salinity (in psu) at $100 \mathrm{~m}$ depth during the GALICIA-XII cruise (September 91), tracing the poleward flowing high salinity current.

Fig. 10. Average concentration of advected, $Y(S, \theta)$, mineralized, $Y_{M}$, and uplifted, $Y=$ $\mathrm{Y}(\mathrm{S}, \theta)+\mathrm{Y}_{\mathrm{M}}$, dissolved inorganic nitrogen, phosphate and silicate (in $\mu \mathrm{mol} \cdot \mathrm{kg}^{-1}$ ) for each zone in all cruises studied. Numbers in brackets beside the mineralized DIN represent the percentage of mineralized ammonium. Numbers in brackets beside the uplifted nutrients are the percentage of mineralized to advected nutrients, $\mathrm{Y}_{\mathrm{M}} / \mathrm{Y}(\mathrm{S}, \theta) \cdot 100$. Values were obtained as the average of all water samples with $\mathrm{AOU}$ $>0$ for each zone in every cruise. Dotted lines delimit the three boundaries within which secondary recycling occurs: the slope, the sediments and the depth of $\mathrm{AOU}=$ 0. 

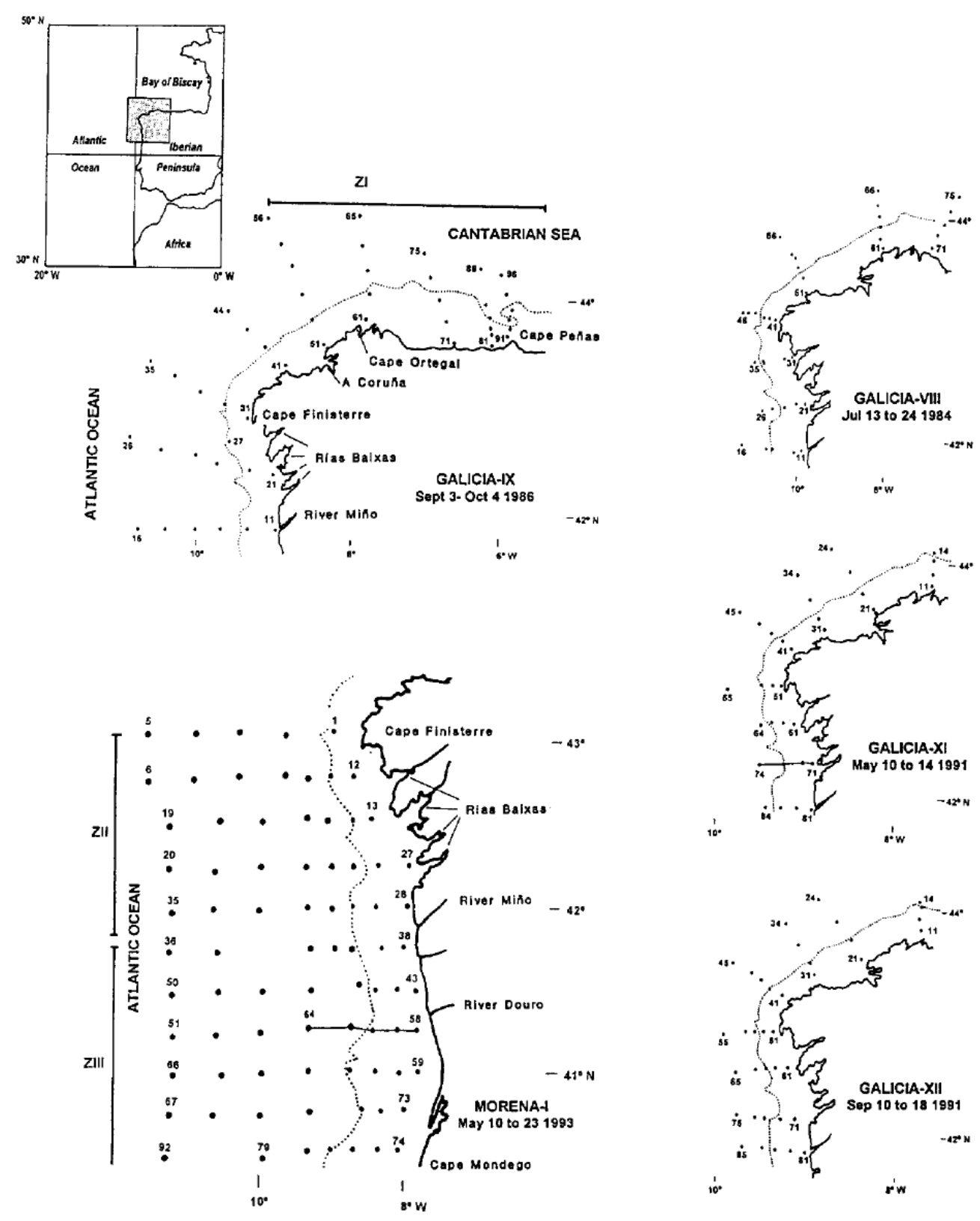

Figure 1 

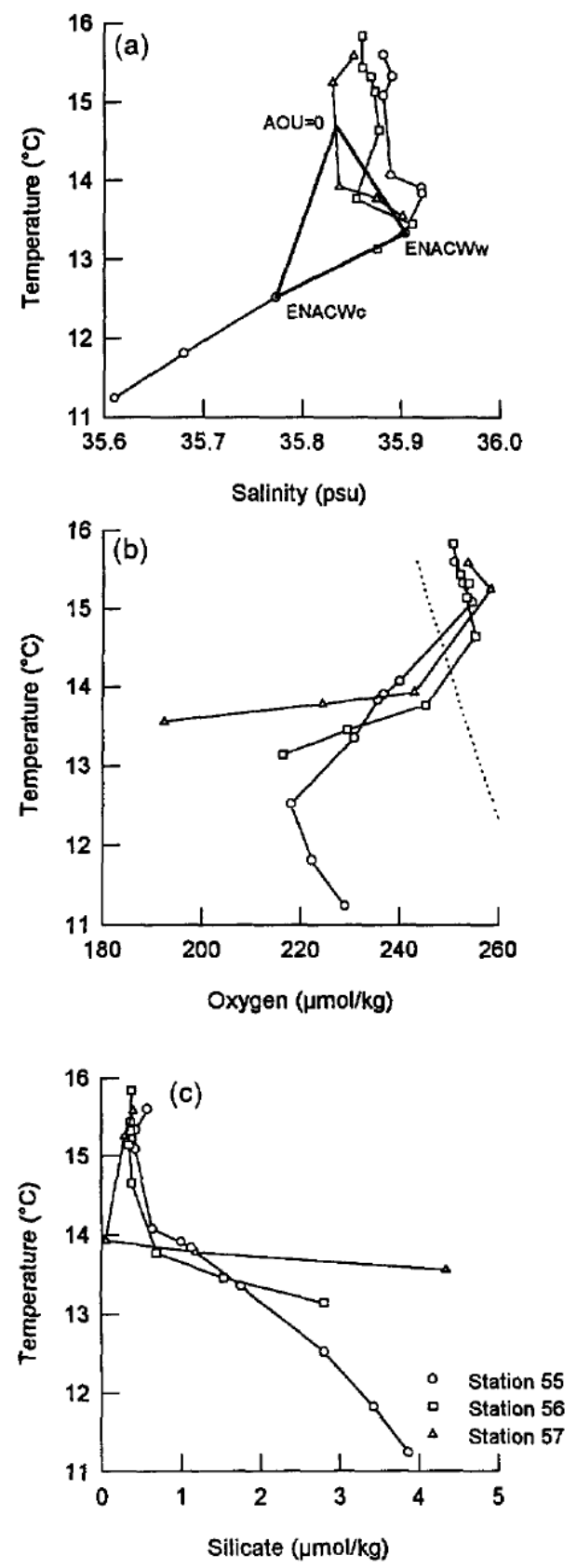

Figure 2 

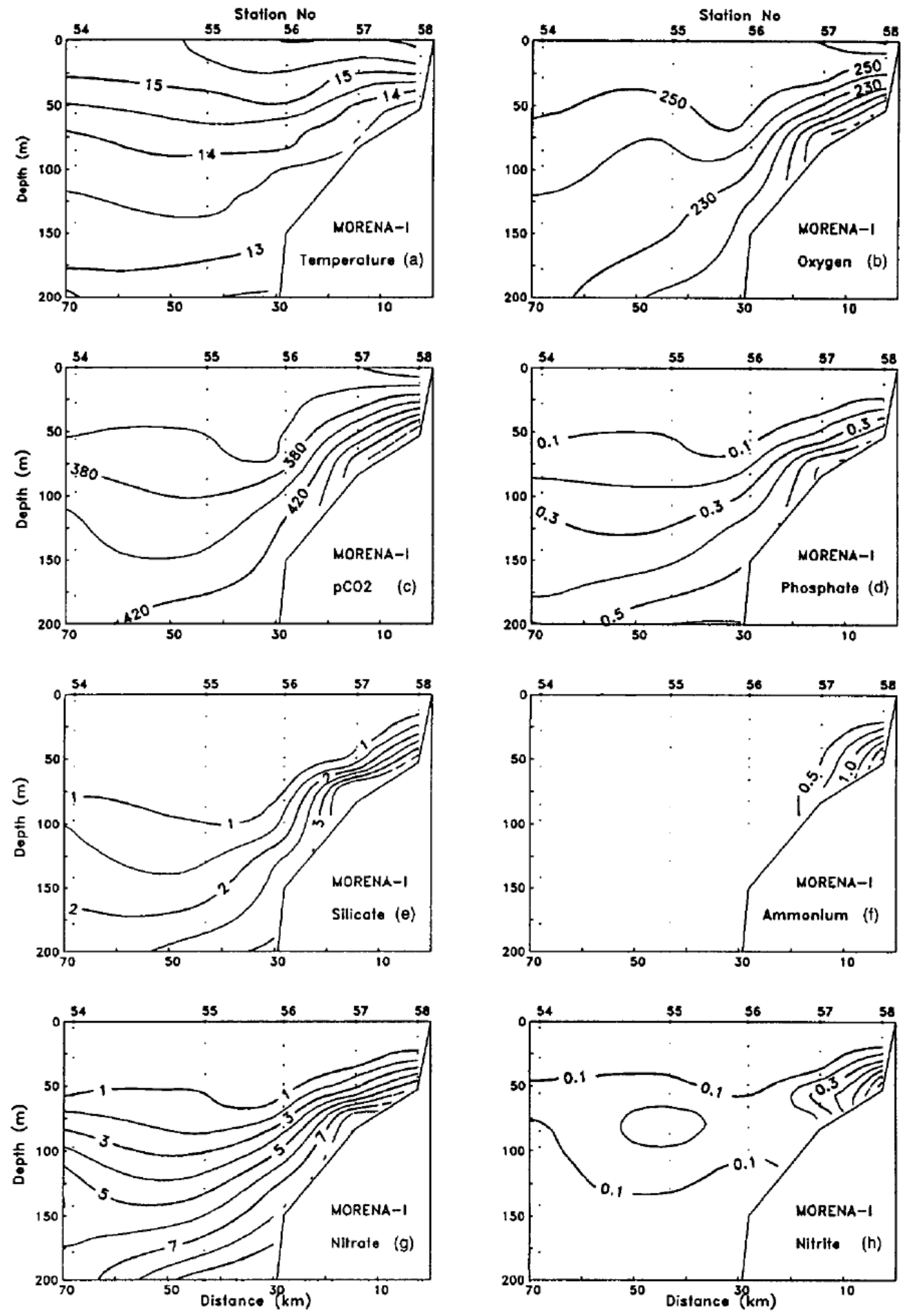

Figure 3 

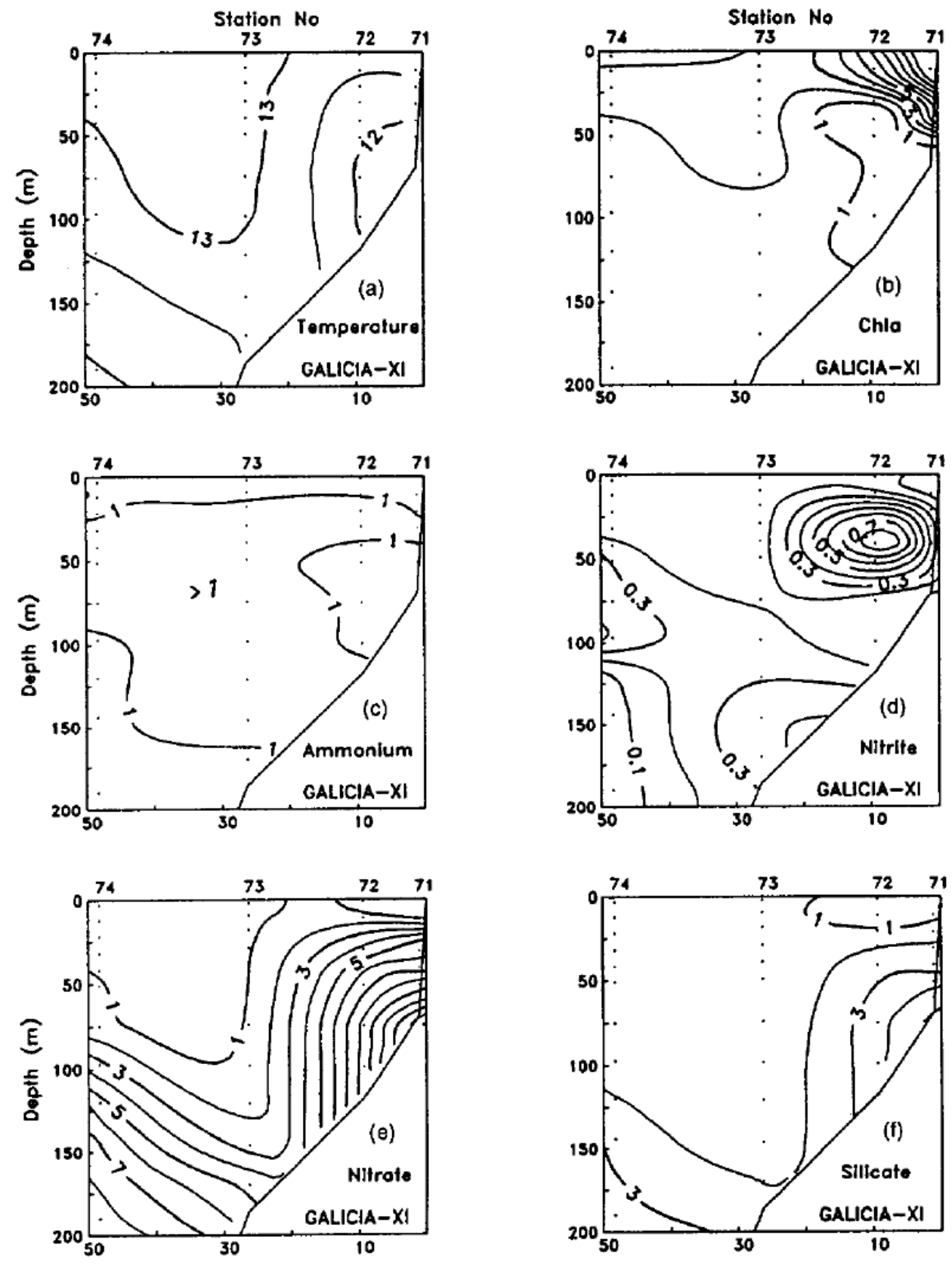

Figure 4 

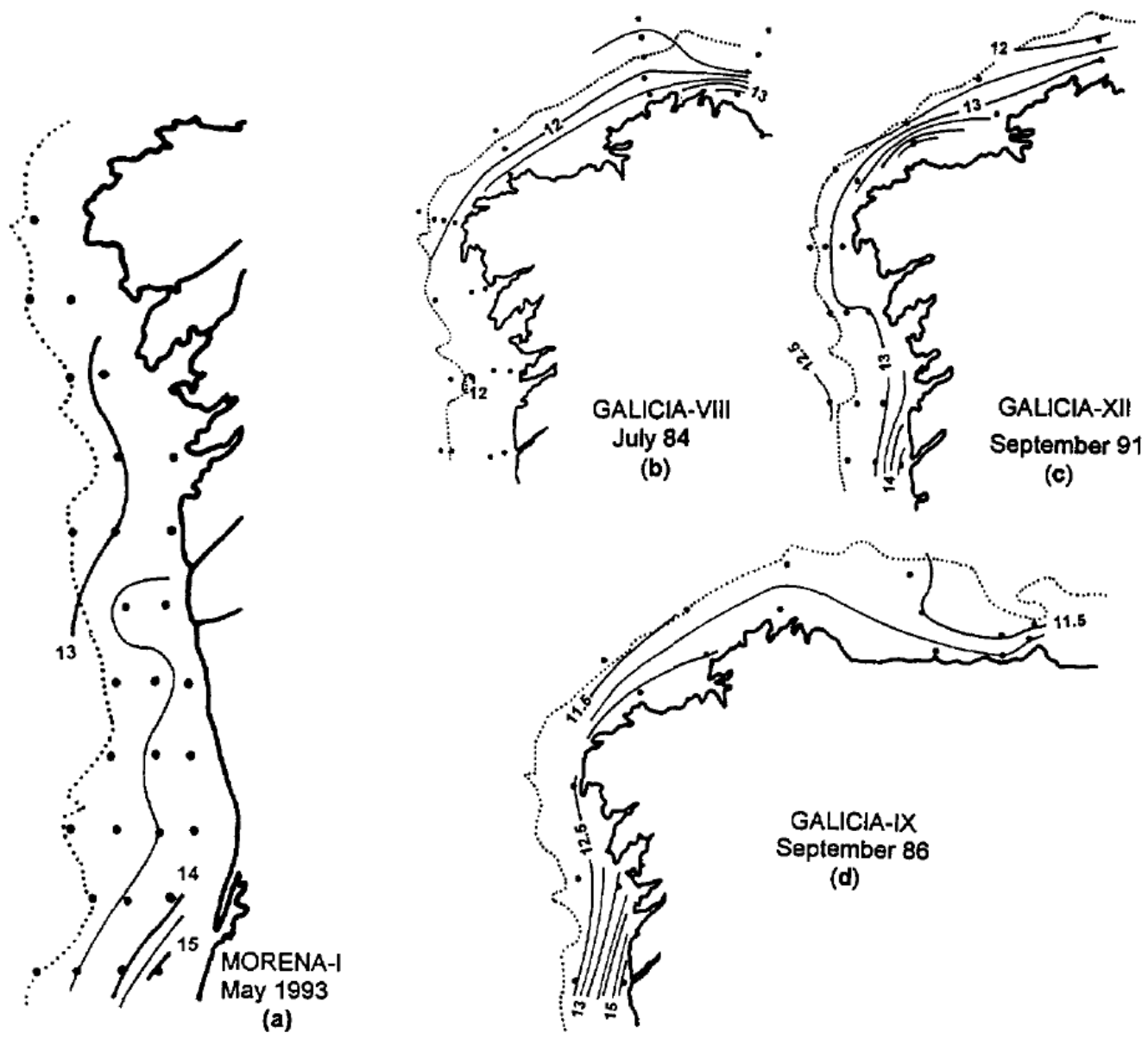

Figure 5 

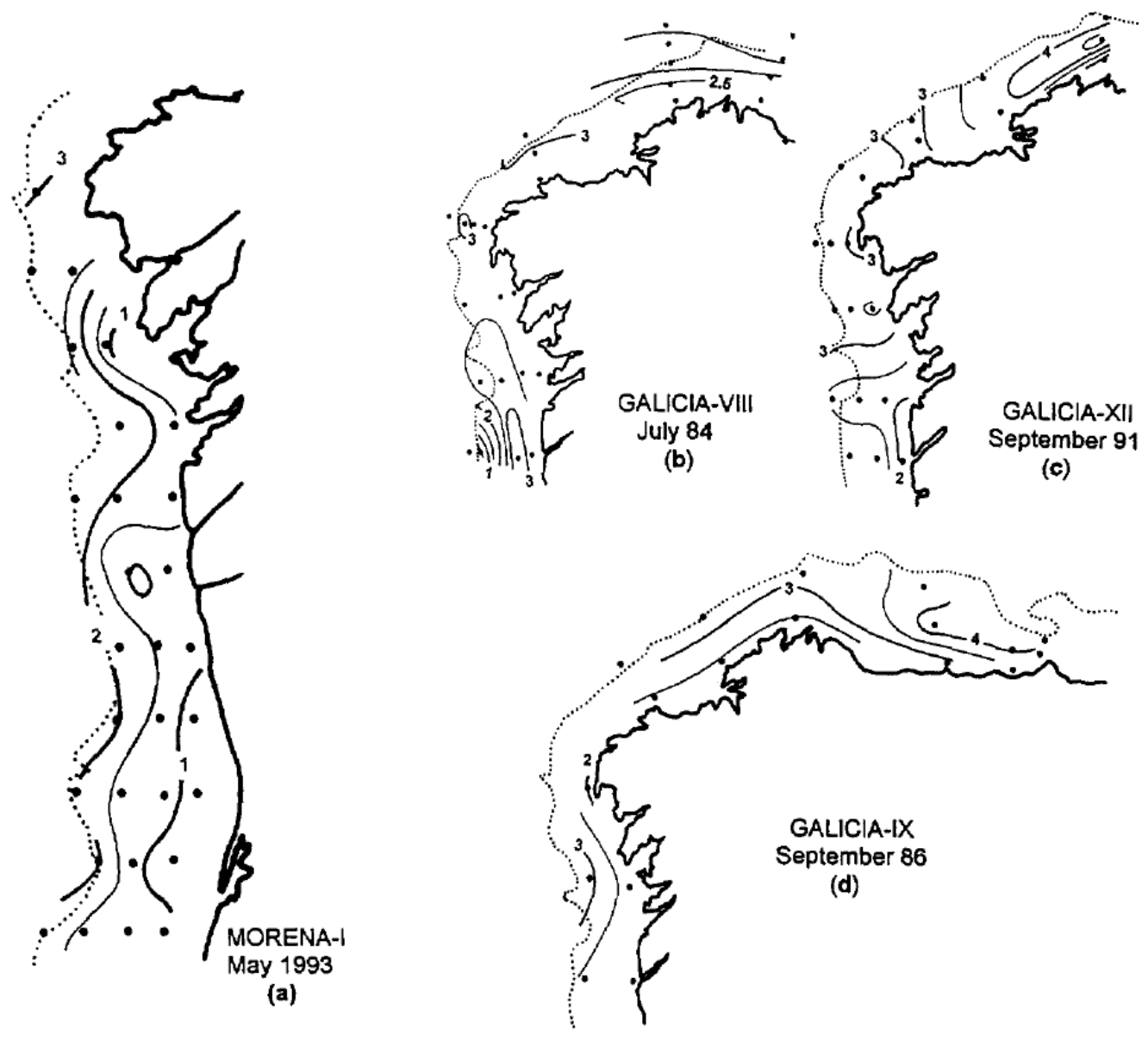

Figure 6 

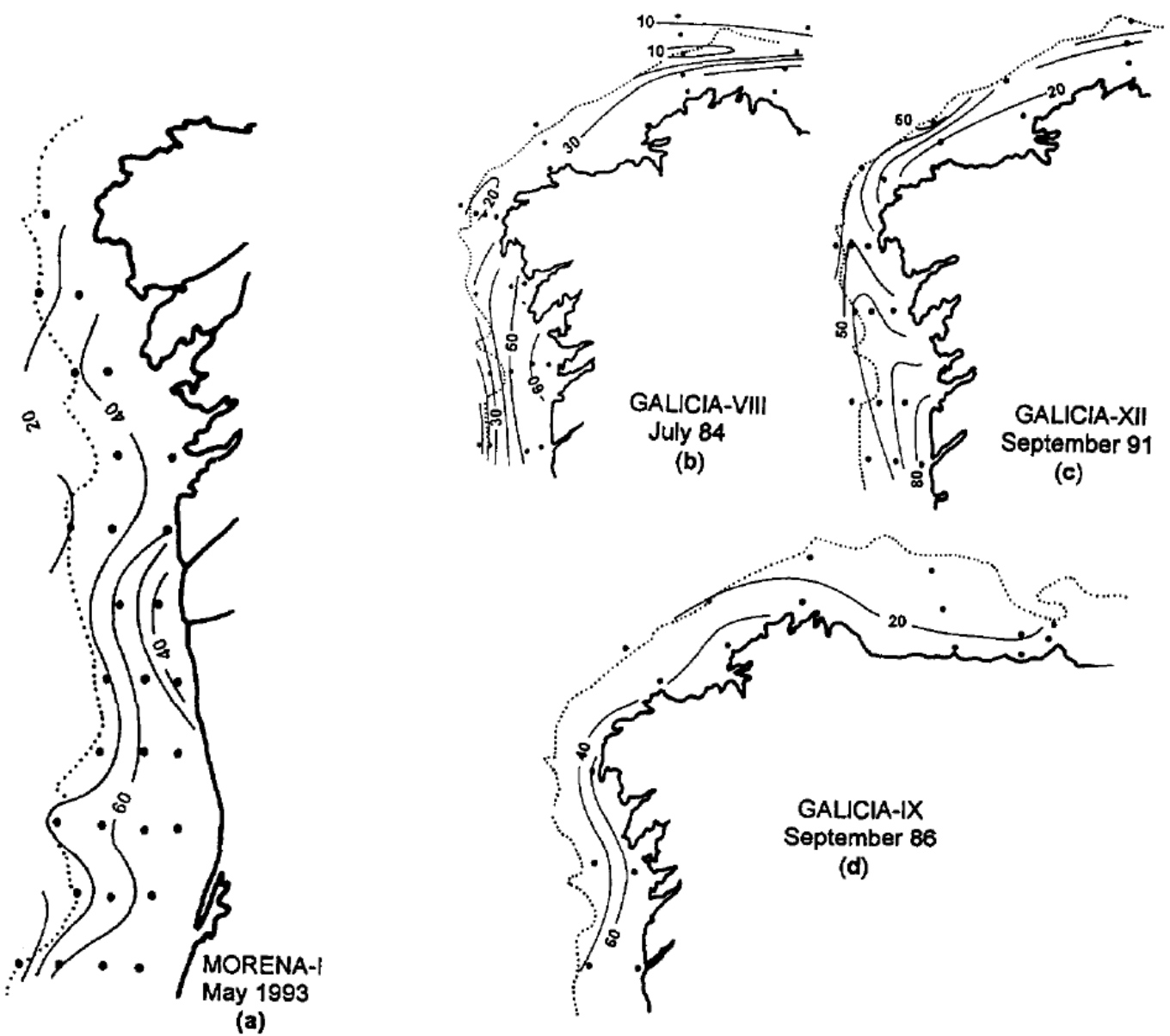

Figure 7 

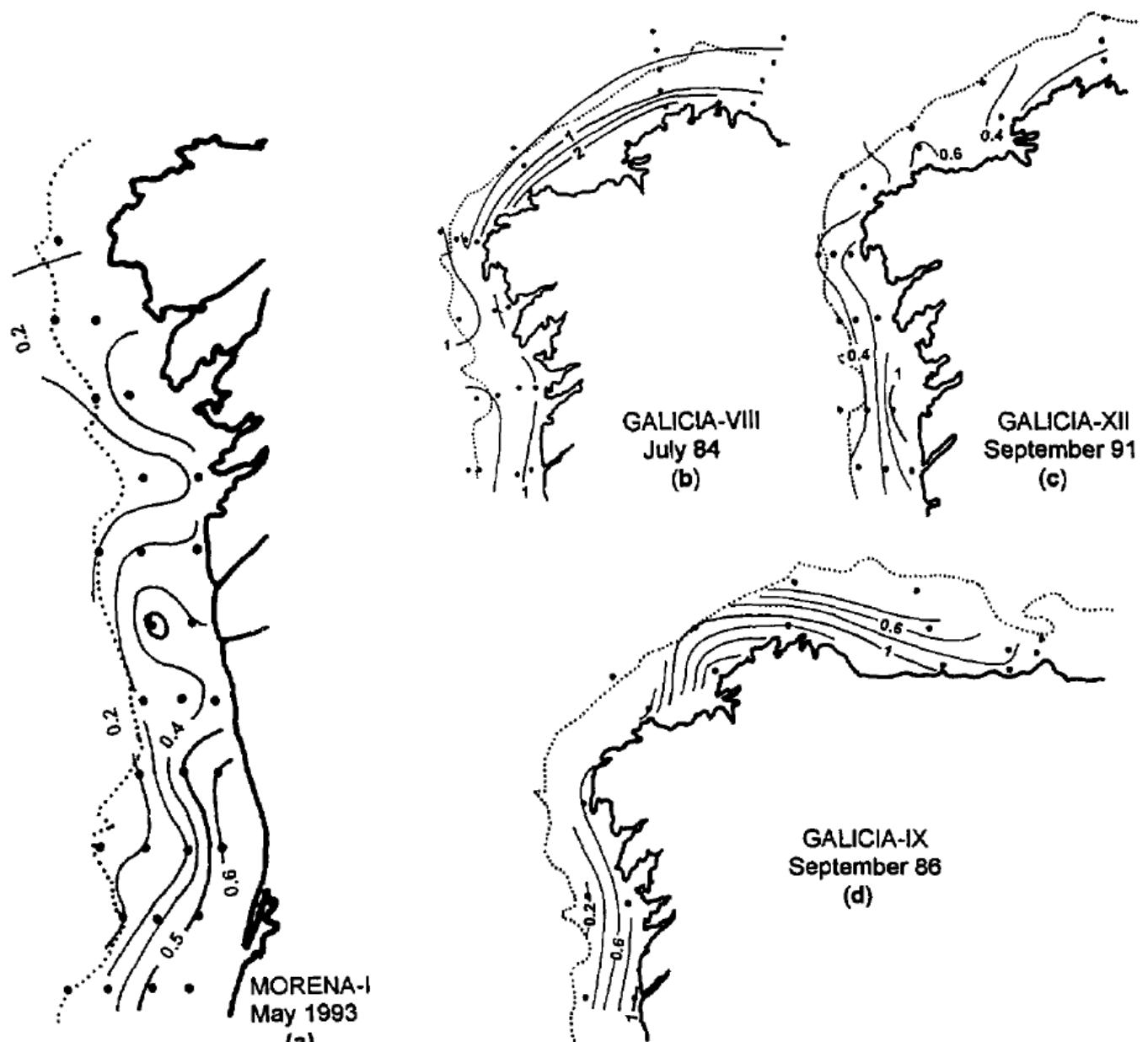

(a)

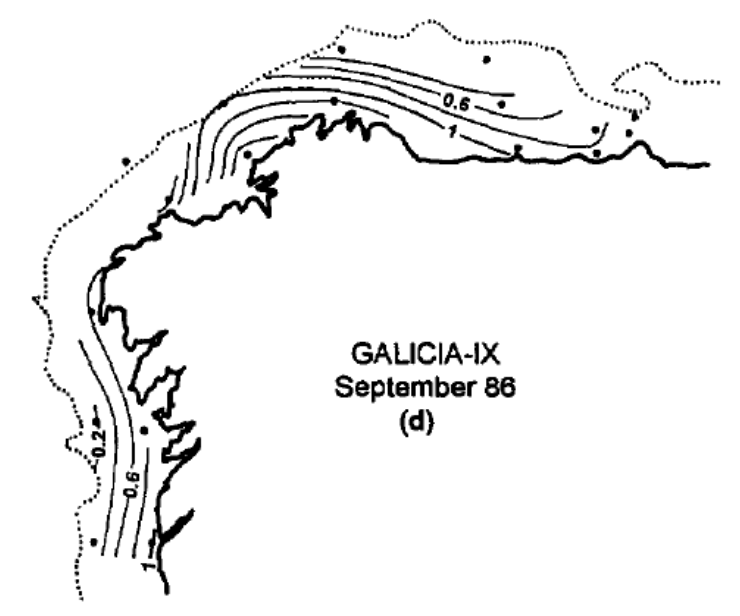

Figure 8 


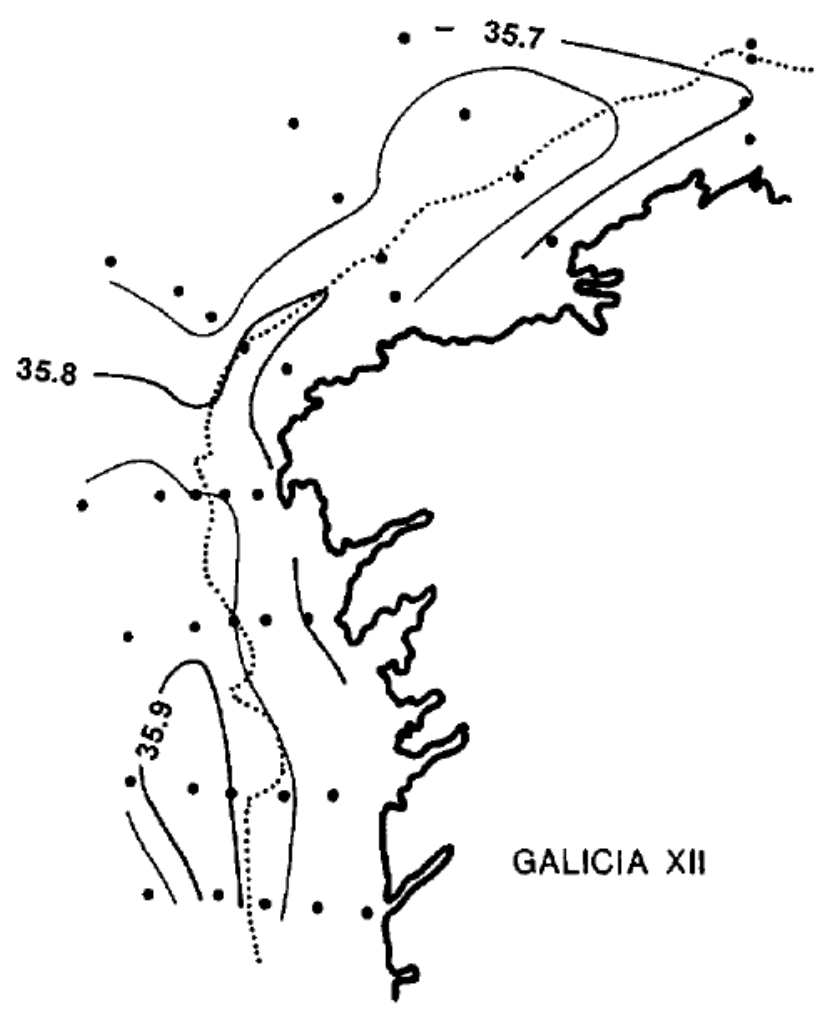

Figure 9 


\section{MORENA-1}

May 93
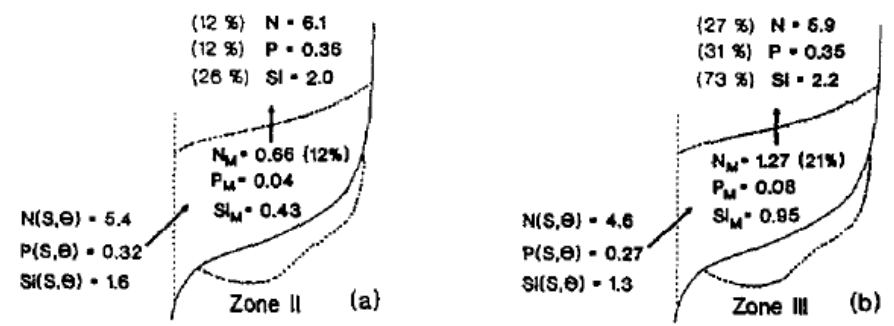
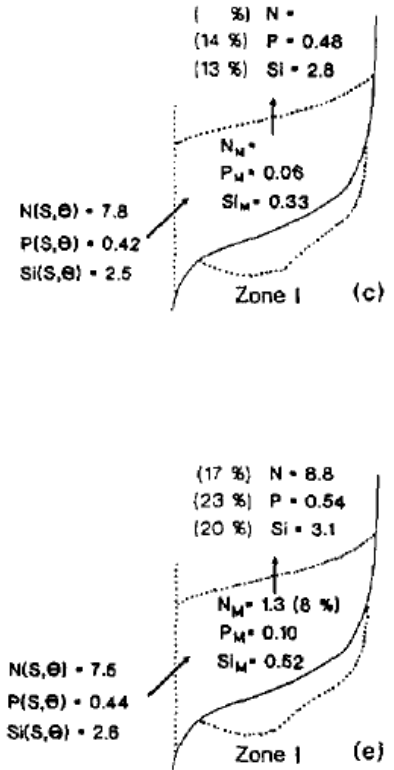

GALICIA-VIII July 84

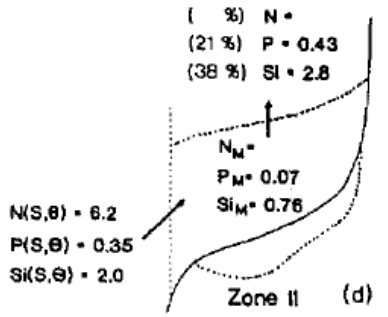

GALICIA-IX

September 86

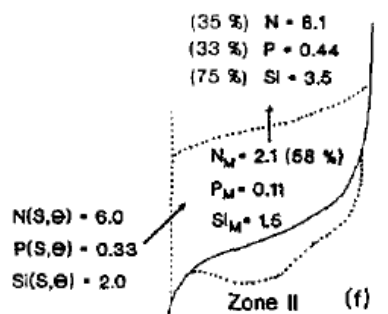

GALICIA-XII

September 91

Figure 10 